Review

\title{
A Literature Review of the COVID-19 Pandemic's Effect on Sustainable HRM
}

\author{
Xiaoyan Liang ${ }^{1, *(\mathbb{D}}$, Xiwei Zhang ${ }^{2}$, Renee Paulet ${ }^{3} \mathbb{C}$ and Leven Jianwen Zheng ${ }^{4}$ \\ 1 International Business School, Xi'an Jiaotong-Liverpool University, Suzhou 215123, China \\ 2 Didasko Digital Research Centre, Didasko Group Affiliated to La Trobe University, Melbourne 3004, Australia; \\ Doris.Zhang@didasko.com \\ 3 Federation Business School, Federation University, Churchill 3842, Australia; renee.paulet@federation.edu.au \\ 4 Lee Shau Kee School of Business and Administration, Hong Kong Metropolitan University, \\ Hong Kong, China; lzheng@hkmu.edu.hk \\ * Correspondence: xiaoyan.liang@xjtlu.edu.cn
}

Citation: Liang, X.; Zhang, X.; Paulet, R.; Zheng, L.J. A Literature Review of the COVID-19 Pandemic's Effect on Sustainable HRM. Sustainability 2022, 14, 2579. https://doi.org/10.3390/ su14052579

Academic Editor: Hyo Sun Jung

Received: 8 February 2022

Accepted: 18 February 2022

Published: 23 February 2022

Publisher's Note: MDPI stays neutral with regard to jurisdictional claims in published maps and institutional affiliations.

Copyright: () 2022 by the authors Licensee MDPI, Basel, Switzerland. This article is an open access article distributed under the terms and conditions of the Creative Commons Attribution (CC BY) license (https:// creativecommons.org/licenses/by/ $4.0 /)$.

\begin{abstract}
The ramifications of the COVID-19 pandemic continue to emerge across all facets of the world of work, including the field of human resource management (HRM). Sustainable HRM, drawing on the triple bottom line elements of the economic, environmental and social pillars of sustainability, provides an ideal basis from which to understand the intersection of the COVID-19 pandemic and HRM. In this systematic literature review, we analyze peer reviewed articles published in the nexus of the pandemic and sustainable HRM, identifying the dimensions and extent of research in this topical area of study. Our CEDEL model-complicator-exposer-disruptor-enabler-legitimizerconceptualizes our understanding of the role of COVID-19 in sustainable HRM. This paper provides a framework from which future studies can benefit when investigating the impacts of COVID-19, and a comprehensive identification of future research avenues.
\end{abstract}

Keywords: the COVID-19 pandemic; sustainable HRM; triple bottom line; sustainability

\section{Introduction}

Scholarly interest in incorporating sustainability into the human resource management (HRM) of organizations has been growing in the last two decades (e.g., [1-6]). The COVID19 global pandemic and its aftermath have accentuated the necessity and significance of this trend, with an increasing number of articles published on COVID-19 and sustainable human resource management (sustainable HRM, hereafter) (e.g., [7-9]). There has been a variety of approaches and definitions for sustainable HRM in the literature. Based on Dyllick and Muff's [10] business sustainability typology, Aust et al. [1] classified four sustainable HRM types following a largely chronological order: sustainable HRM as socially responsible HRM activities, sustainable HRM as green HRM, sustainable HRM as triple bottom line HRM, and sustainable HRM as common good HRM. We take a pluralistic and eclectic approach to the definition of sustainable HRM, which comprises all these four approaches, to ensure all key literature is captured. Following this definition, HRM's focus on the management of employees at work is particularly relevant in understanding the implications of COVID-19 on work and employment. Worldwide, most employees have experienced changes in their work that are linked to the pandemic, from furlough and retrenchment, to increased working from home and the movement of work online, to occupational health and safety concerns for those working on the frontline. However, there remains a gap for a holistic understanding of the impact of COVID-19 on Sustainable HRM. This article addresses this lacuna through a systematic review of the literature intersecting sustainable HRM and the COVID-19 pandemic.

With COVID-19 related publications spiking [11], we argue that the human resource (HR) field remains in want of a review article that systematically takes stock of what we 
now know about the impact of COVID-19 on sustainable HRM for three reasons. First, COVID-19 has had, and will continue to have, a substantial reconfigurational effect on the strategic framing and delivery of human resource strategy in the years to come. Insights into the specific reconfigurational mechanism COVID-19 exerts on sustainable HRM are critical to our understanding and shaping of the future directions of the field. As Vaiman, Cascio, Collings and Swider [12] state, "It's difficult to begin any discussion on the future of talent management without considering the impact of COVID-19" (p. 253). Though the topic is garnering research interest, the approach remains piecemeal and singular. A systematic review approach can provide a holistic and integrated view of the growing field and highlight avenues for future research.

Second, through the centuries, notable global pandemics such as the Black Death in the mid-1300s and the Spanish flu pandemic of 1918 wreaked havoc on societies, but humankind survived through resilience and drawing lessons from experiences and reflection. COVID-19 represents the latest in a long series of pandemics from which epidemiologists, and equally management scholars, could build knowledge and derive lessons. This review article can, therefore, generate insights and novel frameworks, which not only constitute a part of our collective COVID-19 pandemic related knowledge repository, but also inspires and facilitates the knowledge creation process in other fields (e.g., COVID-19 and organizational change; COVID-19 and organizational behavior; COVID-19 and international business) through selective or innovative generalization.

Last but not least, an initial literature search with the key words of "COVID-19" and "Sustainable HRM" yielded over 30 articles (though the final number of articles included in this review is 56). This indicates that there is sufficient research interest on the topic to warrant a review article. This timely literature review will support future research in this contemporary and topical area.

After applying our exclusion criteria (explained in the subsequent methods section), we end up with 56 articles for this review. In the process of analyzing these studies, our inquiries were guided by the following research questions:

- What dimensions of sustainable human resource management have been addressed at the COVID-19 and sustainable HRM nexus, and to what extent have they been studied?

- How has COVID-19 been portrayed to impact sustainable HRM in the extant literature?

- What opportunities exist for future research?

Overall, this review study makes two contributions. First, the incorporation of sustainability into HRM represents an academic trend that continues to gain traction (e.g., [13-15]. The unprecedented COVID-19 pandemic marks a turning point across many academic disciplines, including sustainable HRM. The purpose of this review aims to crystalize knowledge at the nexus between COVID-19 and sustainable HRM. We conceptualized a complicatorexposer-disruptor-enabler-legitimizer (CEDEL) model to account for COVID-19's impact on sustainable HRM. This model constitutes a framework that future COVID-19 oriented scholars can build on and apply, to deepen their investigation into the profound impact of COVID-19 on other academic disciplines.

Second, by providing a systematic review of pandemic related studies on sustainable HRM published in English language journals, this study captures a snapshot of human history, and, concurrently, contributes to the collective knowledge pool of pandemic related lessons learned, from a sustainable HRM perspective. This review article also contributes to the crisis management capacity building of HR practitioners by helping them understand how infectious diseases might complicate, expose, disrupt, enable and legitimize certain workplace practices, HRM policies and stakeholder dynamics, to name a few examples. The knowledge gained could help organizations and HR practitioners to improve their future preparedness for pandemic induced public health emergencies and/or other similar critical incidents.

In the next section, we explain our methods of data collection and analysis. Then we present the main findings from the review, in particular, our CEDEL model. We subsequently propose several future research avenues, both based on CEDEL and beyond it. 


\section{Methods of Data Collection and Analysis}

A systematic literature review summarizes existing evidence and identifies gaps and directions for future research [16]. It differs from a narrative review because of the steps taken to select, scan and analyze the literature, which allows for review of commonalities and disparities and therefore extends the knowledge of the field [17]. Despite the challenge of a cross discipline synthesis of data, this review method remains valuable in terms of identifying the breadth of current propositions on COVID-19 and sustainable HRM, as well as exploring future research opportunities. In this literature paper, qualitative techniques of pattern matching and thematic analysis [18] have been employed to descriptively categorize the journal articles by theoretical lens, geographical focus, methodology and other thematic categories.

To capture the underlying relationship between COVID-19 and sustainable HRM, this study uses predefined selection criteria inspired by principles and guidelines outlined in a preeminent systematic literature review method-PRISMA (preferred reporting items for systematic reviews and meta-analyses) [19]. Following the PRISMA protocol, this systematic literature review offers a revealing standalone evaluation of purposefully considered literature related to COVID-19 and sustainable HRM. Similar to De Cieri and Lazarova [20] and Cooke et al. [21], we adopted the PRISMA approach and modified it into the following steps: (1) search and selection, (2) data extraction and (3) data analysis.

\subsection{Search and Selection}

Our search of the literature was limited to peer reviewed journals, to concentrate on sources that are likely to provide the highest level of impact in the sustainable HRM discipline. Books, reports and other non-peer reviewed publications were explicitly excluded, as journals are preferred sources of knowledge with higher reliability [22]. In searching for relevant primary studies, the initial list of articles was generated using electronic journal database SCOPUS, followed by a secondary search on EBSCO Host database, which are among the most widely recognized and used academic databases in the business and management fields [23].

For the purpose of this study, a combination of terms related to both areas (i.e., COVID-19 and sustainable HRM) were used to identify relevant peer reviewed journal articles. It was assumed that researchers could use the terms 'COVID-19' and 'sustainable $\mathrm{HRM}^{\prime}$ in various ways, therefore, a set of broad search criteria was applied. To exclude or include articles, similar terms were considered in the composition of the keywords. We retrieved existing literature related to COVID-19 and sustainable HRM that were published after January 2020 because we want to understand what has happened with regards to sustainable HRM since the COVID-19 outbreak. The search process and inclusion/exclusion criteria are summarized below:

- Key word ("COVID" OR "COVID-19" OR "coronavirus") AND ("sustainable")

AND ("HRM' OR 'Human Resource Management" OR “HR") OR

AND ("work practices") OR

AND ("employment")

Search in: "Abstract" and "Keywords"

Document type: "Journal article" and "peer-reviewed"

- The inclusion criteria were:

the articles had to discuss COVID-19 within the business context AND

the articles had to discuss COVID-19 and HRM AND

the articles were published in English and have full text available AND

the articles are published after January 2020

- The exclusion criteria were:

Full text not available within the selected database or targeted journals articles that were not written in English

non-peer-reviewed articles, such as book chapters, conference, abstract papers or case 
studies

articles not referring to COVID-19

articles referring to COVID-19 without a focus on HRM

We must acknowledge that our search may not have included all articles published on this topic during the research period because of database unavailability or the use of search terms not reflected in article titles or abstracts. However, we are confident that our comprehensive search revealed the vast majority of the articles on this topic in academic journals. Thus, this data set enables us to outline what has been studied, where studies were conducted in the case of empirical studies, the methodology, the theories used and knowledge gaps that may exist.

\subsection{Data Extraction and Analysis}

The initial keyword search resulted in 233 articles in SCOPUS and 78 in EBSCO Host. Limiting the search to peer reviewed journal articles published in English with full text being available resulted in 185 articles in SCOPUS and 48 in EBSCO Host. This initial set was then used as the basis for further review and subjected to our inclusion/exclusion criteria. In the first stage, all articles were skimmed for consistency and accuracy of the keyword search. A total of 95 articles were selected out of 185 articles in SCOPUS and 34 articles were selected out of 48 articles in EBSCO Host after duplicates were removed. In the second stage, initial coding was conducted based on a preliminary read of the title, abstract and key words (and introduction section if needed) of the articles. This step resulted in a selection of 60 articles in SCOPUS and 13 in EBSCO Host. In the final stage, all remaining articles were read in full, particularly assessing for the relevance to COVID-19 and sustainable HRM, which resulted in a final selection of 56 articles included for data analysis. Among the 56 articles, $45 \%$ are empirical in nature $(\mathrm{n}=25)$ and $55 \%(\mathrm{n}=31)$ are either review papers, conceptual papers, or viewpoint papers. These articles were published in 31 academic journals in the fields of business, healthcare, HRM, management and social science (see Table 1). We then employed a manual content analysis approach and qualitative coding methods to analyze the 56 articles for review purpose [24].

Guided by the most common operationalization of sustainable HRM as triple bottom line HRM [13], the 56 articles were classified into folders, namely, COVID-19 and social sustainability of HRM, COVID-19 and environmental sustainability of HRM (or green HRM), COVID-19 and economic sustainability of HRM, COVID-19 and sustainable careers. The research team double checked and finalized this coding system through deliberation. Then the team jointly processed these articles via an Excel spreadsheet, recording the authors, year of publication, journal, type of article (e.g., empirical or conceptual paper), research objective, key words, theories used, research questions, methodology, findings and our analysis of the aspects of HR studied.

A deeper thematic analysis of the 56 papers was then undertaken. Clusters of themes and subthemes emerged. For example, articles in the folder of COVID-19 and the social sustainability of HRM further revealed subthemes such as employee's wellbeing amidst COVID-19 ( $\mathrm{n}=21)$, HRM practices and systems amidst COVID-19 ( $\mathrm{n}=22)$, COVID-19 and sustainable careers $(n=6)$, and corporate social responsibility (CSR) amidst COVID-19 $(n=3)$. This process was replicated until all articles were coded. The subsequent analysis included the thematic and mathematical extraction of information under the guidance of the research questions. We acknowledge that this qualitative approach is laced with a certain level of subjectivism, but our double checking of the codes enhances the reliability and consistency of the data processing and interpretation of the qualitative data [24]. 
Table 1. Scholarly journals publishing articles on COVID-19 related to sustainable HRM issues.

\begin{tabular}{|c|c|c|}
\hline Discipline & Journal Titles & $\begin{array}{l}\text { No. of Articles Related to the } \\
\text { Impact of COVID-19 on } \\
\text { Sustainable HRM }\end{array}$ \\
\hline \multirow{5}{*}{ Business } & Business Strategy and The Environment & 1 \\
\hline & Compensation $\mathcal{E}$ Benefits Review & 1 \\
\hline & European Journal of Marketing and Economics & 1 \\
\hline & Journal of Business \& Economics & 1 \\
\hline & Journal of Business Research & 2 \\
\hline \multirow{2}{*}{ Healthcare } & $\begin{array}{l}\text { International Journal of Environmental Research } \\
\text { and Public Health }\end{array}$ & 1 \\
\hline & International Nursing Review & 1 \\
\hline \multirow{8}{*}{ HRM } & Advances in Developing Human Resources & 3 \\
\hline & Asia Pacific Journal of Human Resources & 3 \\
\hline & Human Resource Development International & 3 \\
\hline & International Journal of Human & \\
\hline & Resource Management & 1 \\
\hline & Journal of Career Development & 1 \\
\hline & Journal of Vocational Behaviour & 1 \\
\hline & New Zealand Journal of Employment Relations & 1 \\
\hline \multirow{12}{*}{ Management } & Business and Management Studies & 1 \\
\hline & Human Resource Management & 2 \\
\hline & Human Resource Management Journal & 2 \\
\hline & Human Resource Management Review & 3 \\
\hline & International Journal of Contemporary & \\
\hline & Hospitality Management & 1 \\
\hline & International Journal of Hospitality Management & 4 \\
\hline & Journal of Intercultural Management & 1 \\
\hline & Journal of Management & 1 \\
\hline & Journal of Management Studies & 4 \\
\hline & $\begin{array}{l}\text { Management Research: Journal of The } \\
\text { Iberoamerican Academy of Management }\end{array}$ & 1 \\
\hline & Uncertain Supply Chain Management & 1 \\
\hline \multirow{6}{*}{ Social science } & $\begin{array}{l}\text { International Journal Of Sociology and } \\
\text { Social Policy }\end{array}$ & 1 \\
\hline & Journal of Applied Psychology & 2 \\
\hline & Journal of Studies and Research in & 1 \\
\hline & Organizational Dynamics & 3 \\
\hline & Sustainability & 6 \\
\hline & Worldwide Hospitality and Tourism Themes & 1 \\
\hline
\end{tabular}

\section{Main Findings}

The conceptualization of sustainable HRM in the COVID-19 related literature is varied. A key focus within the literature was on sustainable HRM as socially responsible HRM $(n=52)($ e.g., $[25,26])$, with limited consideration of sustainable HRM as green HRM $(n=3)$ (e.g., [27]) and sustainable HRM as economic $(n=1)$. This is reflective of the conceptualization of sustainable HRM along a triple bottom line approach (e.g., [5]), common within the sustainable HRM field. The focus on social aspects within sustainable HRM, while understandable given the significant person focused impacts of the pandemic, is a notable shift of foci within the broader field. As Paulet, Holland, and Morgan [28] noted, the economic aspect of HRM has been well traversed under the strategic HRM banner, and the environmental aspect had also become a significant focus, with publications in the green HRM area increasing five-fold since 2016.

Following our delineation of articles according to the three key dimensions of sustainable HRM as described above, we then identified the key areas of study. We next 
identified the various roles of COVID-19 on sustainable HRM that emerged through the literature, revealing the pandemic to have varied roles as a complicator, exposer, disrupter, enabler and/or legitimizer on sustainable HRM, represented through our CEDEL model. The process leading to the construction of these aggregate dimensions is illustrated in Tables 3-5 where first order categories and second order themes are presented. Table 2 summarizes these key dimensions of the sustainable HRM in the literature reviewed and the different roles COVID-19 was portrayed to play, which this paper now further explores.

Table 2. Dimensions of sustainable HRM in the literature and the roles of COVID-19.

\begin{tabular}{|c|c|c|}
\hline $\begin{array}{c}\text { Dimension of } \\
\text { Sustainable HRM }\end{array}$ & Areas of Study & Role of COVID-19 \\
\hline \multirow{4}{*}{ Social $(n=52)$} & Employee wellbeing $(n=21)$ & 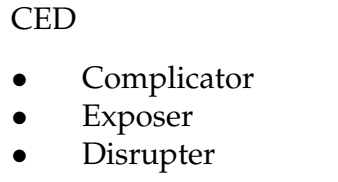 \\
\hline & $\begin{array}{l}\text { HRM practices and systems } \\
(\mathrm{n}=22)\end{array}$ & 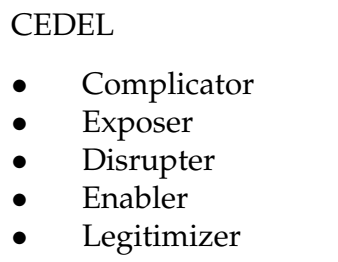 \\
\hline & $\begin{array}{l}\text { Sustainable career } \\
(\mathrm{n}=6)\end{array}$ & 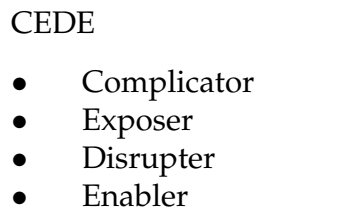 \\
\hline & $\operatorname{CSR}(n=3)$ & Legitimizer \\
\hline \multirow{2}{*}{ Environmental $(\mathrm{n}=3)$} & $\begin{array}{l}\text { Implications of COVID-19 on } \\
\text { environmental sustainability }(n=2)\end{array}$ & Complicator \\
\hline & Green HRM and performance $(\mathrm{n}=1)$ & Exposer \\
\hline Economic $(\mathrm{n}=1)$ & $\begin{array}{l}\text { SMART team design and performance } \\
\text { during COVID-19 }(\mathrm{n}=1)\end{array}$ & Enabler \\
\hline
\end{tabular}

\subsection{COVID-19 and the Social Sustainability of HRM}

Four major themes emerged from the articles focused on COVID-19 and the social dimension of sustainable HRM: employee wellbeing $(\mathrm{n}=21)$, HRM practices and systems $(n=22)$, career implications of COVID-19 with an implicit sustainability focus $(n=6)$, and CSR $(n=3)$. These four key dimensions are now explored in more detail and categorized within our CEDEL model.

\subsubsection{Employees' Wellbeing Amidst COVID}

The COVID-19 pandemic has brought employees' wellbeing issues to the forefront of sustainable HRM. The current COVID-19 related sustainable HRM literature this review included were devoted to examining the effect of COVID-19 on employees' wellbeing, in particular, special groups such as the self-employed [29], young people and women with unstable employment relationships and in temporary work situations [30], people with mental disabilities (PWMDs) [31] and international employees [20]. Our coding revealed that the roles COVID-19 played in the various employee wellbeing issues could be conceptualized by the "CED" components of the CEDEL model, namely, complicatorexposer-disruptor. See Table 3 below for a summary. 
Table 3. The impact of COVID-19 on employee wellbeing $(n=21)$.

\begin{tabular}{|c|c|c|c|c|c|c|}
\hline $\begin{array}{c}\text { Aggregate } \\
\text { Dimensions }\end{array}$ & $\begin{array}{c}\text { Second Order } \\
\text { Themes }\end{array}$ & $\begin{array}{l}\text { First Order } \\
\text { Categories }\end{array}$ & $\begin{array}{l}\text { Theoretical } \\
\text { Underpinning }\end{array}$ & Factors & $\begin{array}{l}\text { Type and } \\
\text { Contexts }\end{array}$ & Examples \\
\hline & & & $\begin{array}{l}\text { Ethics of care, } \\
\text { Human resource } \\
\text { development } \\
\text { (HRD) approach, } \\
\text { Work-life conflict }\end{array}$ & $\begin{array}{l}\text { Human resource } \\
\text { development } \\
\text { (HRD) } \\
\text { interventions } \\
\text { Gender }\end{array}$ & Conceptual & [32-35] \\
\hline Complicator & $\begin{array}{l}\text { Amplifying or } \\
\text { diminishing the } \\
\text { existing } \\
\text { challenges faced } \\
\text { by employees }\end{array}$ & $\begin{array}{l}\text { Flexible working } \\
\text { Working from } \\
\text { home (WFH) } \\
\text { Work-life balance } \\
\text { Work-life } \\
\text { enrichment } \\
\text { Gender equity }\end{array}$ & $\begin{array}{l}\text { Work-life conflict } \\
\text { Sustainable } \\
\text { development } \\
\text { goals } \\
\text { Sustainable } \\
\text { human capital } \\
\text { development }\end{array}$ & $\begin{array}{l}\text { Amplifying } \\
\text { challenges: add } \\
\text { domestic duties } \\
\text { to women, } \\
\text { strengthen gender } \\
\text { roles, increase } \\
\text { work-family } \\
\text { conflict and stress. } \\
\text { Diminishing: } \\
\text { reduce } \\
\text { commuting time; } \\
\text { more personal } \\
\text { time. } \\
\text { Gender } \\
\text { (moderator); age. } \\
\text { Generational } \\
\text { differences; } \\
\text { educational level; } \\
\text { occupational; } \\
\text { experience with } \\
\text { teleworking; } \\
\text { duration and } \\
\text { intensity of } \\
\text { telework } \\
\text { Mental } \\
\text { disabilities } \\
\text { Work-life } \\
\text { enrichment }\end{array}$ & $\begin{array}{l}\text { India: mixed } \\
\text { methods, } \\
\text { working women } \\
\text { of Mumbai } \\
\text { metropolitan } \\
\text { Lithuania: } \\
\text { quantitative, } 436 \\
\text { teleworkers. } \\
\text { UK: mixed } \\
\text { methods, people } \\
\text { with mental } \\
\text { disabilities } \\
\text { (PWMDs). } \\
\text { Poland: } \\
\text { qualitative, } 18 \text { HR } \\
\text { professionals and } \\
\text { 16 employees. } \\
\text { US: quantitative, } \\
\text { two studies, } \\
\text { latent transition } \\
\text { analysis. } \\
\text { Romania: } \\
\text { quantitative. }\end{array}$ & {$[26,31,36-39]$} \\
\hline Exposer & $\begin{array}{l}\text { Exposing } \\
\text { structural } \\
\text { inequalities in } \\
\text { workplaces or } \\
\text { factors that } \\
\text { impact on } \\
\text { employees } \\
\text { wellbeing. }\end{array}$ & $\begin{array}{l}\text { Employee } \\
\text { wellbeing. } \\
\text { Job security. } \\
\text { Job satisfaction. } \\
\text { Social } \\
\text { inequalities. }\end{array}$ & $\begin{array}{l}\text { Job demands- } \\
\text { resources model } \\
\text { (JD-R model); } \\
\text { psychological } \\
\text { wellbeing; } \\
\text { subjective } \\
\text { wellbeing. } \\
\text { JDCS model (job } \\
\text { demand-control- } \\
\text { support). } \\
\text { Systems } \\
\text { perspective. }\end{array}$ & $\begin{array}{l}\text { Positive factors } \\
\text { (resources) and } \\
\text { negative factors } \\
\text { (demands); } \\
\text { professional } \\
\text { identity; } \\
\text { job satisfaction } \\
\text { (moderator). } \\
\text { Generational } \\
\text { differences } \\
\text { (moderator) } \\
\text { Regions, age, } \\
\text { gender, } \\
\text { employment } \\
\text { modes. } \\
\text { Job demands; } \\
\text { labor control } \\
\text { (mediator); } \\
\text { Social } \\
\text { relationships and } \\
\text { perceived social } \\
\text { support } \\
\text { (mediator). } \\
\text { Employee } \\
\text { wellbeing based } \\
\text { on sustainable } \\
\text { HRM principles } \\
\text { leads to increased } \\
\text { organiza- } \\
\text { tional trust. }\end{array}$ & $\begin{array}{l}\text { India: hotel } \\
\text { employees. } \\
\text { China: university } \\
\text { teachers. } \\
\text { South Korea: } \\
\text { Seoul, employees. } \\
\text { Portugal: all } \\
\text { employees. } \\
\text { Ecuador: the } \\
\text { self-employed. } \\
\text { Review article. }\end{array}$ & {$[7,29,30,40-43]$} \\
\hline
\end{tabular}


Table 3. Cont.

\begin{tabular}{|c|c|c|c|c|c|c|}
\hline $\begin{array}{l}\text { Aggregate } \\
\text { Dimensions }\end{array}$ & $\begin{array}{l}\text { Second Order } \\
\text { Themes }\end{array}$ & $\begin{array}{l}\text { First Order } \\
\text { Categories }\end{array}$ & $\begin{array}{l}\text { Theoretical } \\
\text { Underpinning }\end{array}$ & Factors & $\begin{array}{l}\text { Type and } \\
\text { Contexts }\end{array}$ & Examples \\
\hline & \multirow{2}{*}{$\begin{array}{l}\text { Exposing } \\
\text { vulnerabilities } \\
\text { with certain } \\
\text { employee groups }\end{array}$} & $\begin{array}{l}\text { Flexible global } \\
\text { working } \\
\text { arrangements } \\
\text { (FGWAs). }\end{array}$ & $\begin{array}{l}\text { Value creation. } \\
\text { Value destruction. } \\
\text { International } \\
\text { HRM. }\end{array}$ & $\begin{array}{l}\text { Forms of global } \\
\text { working } \\
\text { arrangements. } \\
\text { Functionality. } \\
\text { Health and } \\
\text { wellbeing. } \\
\text { Strategic and } \\
\text { sustainable } \\
\text { IHRM. }\end{array}$ & $\begin{array}{l}\text { Review of flexible } \\
\text { global working } \\
\text { arrangements }\end{array}$ & {$[44]$} \\
\hline & & $\begin{array}{l}\text { OHS of } \\
\text { international } \\
\text { employees }\end{array}$ & $\begin{array}{l}\text { Global work. } \\
\text { Health and safety. }\end{array}$ & $\begin{array}{l}\text { Personal health } \\
\text { and safety; health } \\
\text { and safety } \\
\text { behavior factors; } \\
\text { social and family } \\
\text { factors; job/work } \\
\text { related factors; } \\
\text { organizational } \\
\text { factors and } \\
\text { external factors. } \\
\text { Employees' } \\
\text { health. }\end{array}$ & $\begin{array}{l}\text { Review on health } \\
\text { and safety of } \\
\text { international } \\
\text { employees. } \\
\text { Poland: } \\
\text { quantitative. }\end{array}$ & {$[20,45]$} \\
\hline Disrupter & $\begin{array}{l}\text { Altering the } \\
\text { normal work } \\
\text { conditions of } \\
\text { employees and } \\
\text { their experiences } \\
\text { of person- } \\
\text { environment fit } \\
\text { (P-E) fit as well as } \\
\text { sociopsychologi- } \\
\text { cal issues. }\end{array}$ & $\begin{array}{l}\text { Person- } \\
\text { environment } \\
(P-E) \text { fit }\end{array}$ & $\begin{array}{l}\text { P-E fit; } \\
\text { HRM }\end{array}$ & $\begin{array}{l}\text { Work-family } \\
\text { effects. } \\
\text { Family structure. } \\
\text { Entrepreneurship. }\end{array}$ & Conceptual & {$[40,46]$} \\
\hline
\end{tabular}

\section{COVID-19 as a Complicator}

COVID-19 further complicated the extant discussions on the benefits and drawbacks of working from home (WFH) by adding an additional layer of complexity. Some studies argue that COVID-19 amplifies the challenges of balancing work and life for employees by creating a new remote work life for employees, leading to an added level of stress likely to bring out overwork, burnout and lower employee performance (e.g., [35-37]). In contrast, some scholars argue COVID-19 induced WFH actually diminishes challenges experienced by employees, such as reducing stress related to communication, ability to work without being constantly monitored by managers, and saving time commuting to workplaces. In addition, WFH ensured business continuity, facilitated social distancing and containment of the virus, and enhanced employee wellbeing (e.g., [34]). This landscape is further complicated by the identification of possible mediators of this relationship. Raišiene et al. [26] reported, from a Lithuanian employees' perspective, that gender, age, generation, experiences with telework and duration of telework experience might be mediators of COVID-19's impact on WFH. Further research points to issues specific to some cohorts of employees, with Warmate et al. [31] finding little or no flexible opportunities in place to help people with mental disabilities (PWMDs) succeed in their job roles despite the rights of PWMDs as denoted in the Sustainable Development Goals [47-49].

The research points to COVID-19 complicating these pre-existing issues surrounding WFH arrangements. As Green et al. [34] rightfully point out, the experiences of WFH during the pandemic are likely to shape the future of WFH for employees, organizations, and special groups of workers. It remains unknown in which direction this shaping effect takes place. We speculate that, in light of the complicated and inconclusive effect of COVID-19 on WFH in the literature, WFH in the post pandemic era might also remain divergent, with 
some organizations reverting to business as normal, and other organizations seeking to innovatively embed work from home on a more permanent basis.

\section{COVID-19 as an Exposer}

COVID-19 was found to play the role of an exposer in the literature, unmasking workplace inequalities and injustices, and exposing troubling differential treatment and status of employees based on gender, race, skills and social class. For example, exposure to the risks of contracting the coronavirus gravitates towards women and minorities (e.g., foreign born immigrants), who disproportionately represent the majority of care workers (in US and UK) [33]. Further, gig workers [48,50], blue collar employees, and those in hospitality, tourism and production industries were affected the most, as they experienced job losses, increased job insecurity, reduced income and career shocks [51]. The potential for fractures among employee groups has also increased [52].

COVID-19 also "exposed" factors that affect the wellbeing of employees of different industries across country contexts. For example, Agarwal [40] explores factors that affect the wellbeing of hotel employees in India from a job demands-resources theory. Jung et al. [42] showed that the perceptions of job insecurity of deluxe hotel employees in Seoul had negative effects on engagement. In addition, the engagement of employees fully mediated the relationship between perceptions of job insecurity and turnover intent, and job insecurity caused by COVID-19 had a greater influence on generation $Y$ than generation $\mathrm{X}$ in reducing job engagement, indicating that the negative impact of job insecurity is higher in generation $\mathrm{Y}$.

Two conceptual papers exposed vulnerabilities with special groups. COVID-19 has presented unprecedented challenges to international employees. De Cieri and Lazarova [20] performed a review of 180 articles on the occupational health and safety of international employees to find that international work is associated with negative psychological, physical and physiological health outcomes and risky behaviors. Jooss et al. [44] offers the first systematic, integrative review of 100 articles on flexible global working arrangements (FGWAs). The review indicates that these forms of global work appear to be a somewhat overlooked double edged sword, in that they may confer significant but unrealized value for multinationals alongside hidden, adverse consequences for individuals.

\section{COVID-19 as a Disrupter}

COVID-19 altered the normal work conditions of employees and their attendant experiences of person-environment fit (P-E), as well as exacerbating sociopsychological issues. For example, due to lockdown, employees' social, relational and communicational goals were frustrated, their expectations of recruitment and training programs (having changed to virtual) were reset, and these would invariably influence their P-E fit, wellbeing, satisfaction and productivity [46]. Further, Agarwal [40] found that COVID-19 has impacted the HRM process by eroding person-job fit and having disproportionate family effects on employees [46], in turn affecting the wellbeing of employees [53]. COVID-19 also created unique challenges for employees with alternative family structures, i.e., single and childless employees, such as increasing their often high risks of loneliness and feelings of social exclusion, already reported in the existing literature [54].

\subsubsection{HRM Practices and Systems Amidst COVID}

Research exploring the COVID-19 and sustainable HRM nexus revealed a focus on HRM practices and systems, with 22 articles focused on this stream. The HRM practices covered included: furlough practices, employee turnover/retention, training and development during COVID-19, and compensation and benefits. Additional studies viewed HRM as a system to investigate its interplay with the pandemic. For example, He et al. [25] examine socially responsible HRM's impact on employee's pandemic induced fears and Manuti et al. [55] explore HRM's impact on positive organizational behaviors. Within the HRM practices and systems dimension, all five aspects of the CEDEL model emerged: com- 
plicator, exposer, disrupter, enabler and legitimizer, summarized in Table 4 and explored in more detail below.

Table 4. Impact of COVID-19 on HRM practices and systems $(n=22)$.

\begin{tabular}{|c|c|c|c|c|c|c|}
\hline $\begin{array}{c}\text { Aggregate } \\
\text { Dimensions }\end{array}$ & $\begin{array}{c}\text { Second } \\
\text { Order Themes }\end{array}$ & $\begin{array}{l}\text { First Order } \\
\text { Categories }\end{array}$ & $\begin{array}{l}\text { Theoretical } \\
\text { Underpinning }\end{array}$ & HRM Practices & $\begin{array}{c}\text { Type } \\
\text { and Contexts }\end{array}$ & Examples \\
\hline Complicator & $\begin{array}{l}\text { Amplifying or } \\
\text { diminishing the } \\
\text { effect of some } \\
\text { factors on HRM } \\
\text { practices. }\end{array}$ & $\begin{array}{l}\text { Aged care } \\
\text { workforce } \\
\text { shortage during } \\
\text { COVID-19. } \\
\text { COVID-19 } \\
\text { infection and } \\
\text { death rates } \\
\text { amplified } \\
\text { individual } \\
\text { resistance to join } \\
\text { the sector and } \\
\text { lower worker } \\
\text { satisfaction, } \\
\text { increase turnover } \\
\text { intention. }\end{array}$ & $\begin{array}{l}\text { Factors (personal, } \\
\text { institutional and } \\
\text { societal) affecting } \\
\text { the recruitment } \\
\text { and retention of } \\
\text { suitable care } \\
\text { workers in } \\
\text { aged care. }\end{array}$ & $\begin{array}{l}\text { Recruitment and } \\
\text { retention. }\end{array}$ & $\begin{array}{l}\text { Australia: } \\
\text { qualitative, } \\
32 \text { direct care } \\
\text { workers from } \\
\text { three large not for } \\
\text { profit aged } \\
\text { care organization. }\end{array}$ & [56] \\
\hline Exposer & $\begin{array}{l}\text { Exposing } \\
\text { organizational } \\
\text { practices and/or } \\
\text { core assump- } \\
\text { tions/theories of } \\
\text { the HRM field } \\
\text { were problematic. }\end{array}$ & $\begin{array}{l}\text { Labor } \\
\text { commodification. } \\
\text { Work design, } \\
\text { recruitment and } \\
\text { selection. } \\
\text { Compensation } \\
\text { management. } \\
\text { Job design. }\end{array}$ & $\begin{array}{l}\text { Shareholder } \\
\text { theory. } \\
\text { Labor } \\
\text { commodification. } \\
\text { Strategic HRM. }\end{array}$ & $\begin{array}{l}\text { The flexible firm } \\
\text { model. } \\
\text { The HR } \\
\text { architecture } \\
\text { model. } \\
\text { Primacy of the } \\
\text { stakeholder view } \\
\text { underpinning } \\
\text { strategic HRM. }\end{array}$ & $\begin{array}{l}\text { Viewpoint } \\
\text { papers. }\end{array}$ & {$[8,57,58]$} \\
\hline Disrupter & $\begin{array}{l}\text { Altering the } \\
\text { normal work } \\
\text { conditions of } \\
\text { employees and } \\
\text { their experiences } \\
\text { of HRM practices. }\end{array}$ & $\begin{array}{l}\text { Job search. } \\
\text { Onboarding. } \\
\text { Job insecurity, } \\
\text { health complaints } \\
\text { during isolation. } \\
\text { Risk-taking } \\
\text { behavior and } \\
\text { changes in the } \\
\text { organization. } \\
\text { Mega trends such } \\
\text { as flexible } \\
\text { workforce, } \\
\text { digitalization of } \\
\text { business models, } \\
\text { AI and machine } \\
\text { learning. }\end{array}$ & $\begin{array}{l}\text { Job insecurity. } \\
\text { Work related } \\
\text { attitudes and } \\
\text { turnover } \\
\text { intentions. }\end{array}$ & $\begin{array}{l}\text { Work related } \\
\text { attitudes (job } \\
\text { motivation and } \\
\text { job satisfaction). } \\
\text { Turnover } \\
\text { intentions. } \\
\text { Onboarding } \\
\text { practice. } \\
\text { Job search. }\end{array}$ & $\begin{array}{l}\text { Serbia: } \\
\text { quantitative, } 624 \\
\text { questionnaires } \\
\text { from hospitality } \\
\text { industry. } \\
\text { Conceptual. } \\
\text { US: quantitative, } \\
\text { conceptual. }\end{array}$ & [59-62] \\
\hline Enabler & $\begin{array}{l}\text { Enable } \\
\text { organizations to } \\
\text { put into place } \\
\text { new HRM } \\
\text { policies and } \\
\text { employee } \\
\text { wellbeing } \\
\text { programs. }\end{array}$ & $\begin{array}{l}\text { Role of HRM in } \\
\text { curbing the } \\
\text { adverse impact of } \\
\text { COVID-19: } \\
\text { Workplace } \\
\text { guideline and } \\
\text { support; } \\
\text { Access to } \\
\text { information on } \\
\text { pandemic and } \\
\text { financial benefits; } \\
\text { Health related } \\
\text { factors and } \\
\text { quality of life; } \\
\text { Communication } \\
\text { and promoting } \\
\text { message. } \\
\text { A review of the } \\
\text { Covid-19 } \\
\text { pandemic on HR } \\
\text { practices }\end{array}$ & $\begin{array}{l}\text { Intrinsic and } \\
\text { extrinsic } \\
\text { motivation }\end{array}$ & $\begin{array}{l}\text { Retention } \\
\text { Recruitment and } \\
\text { selection, remote } \\
\text { working, } \\
\text { motivating } \\
\text { employees, } \\
\text { re-skilling and } \\
\text { communicating }\end{array}$ & $\begin{array}{l}\text { Egypt: } \\
\text { quantitative, } \\
\text { medical supplies } \\
\text { sector. } \\
\text { Review }\end{array}$ & {$[63,64]$} \\
\hline
\end{tabular}


Table 4. Cont.

\begin{tabular}{|c|c|c|c|c|c|c|}
\hline $\begin{array}{c}\text { Aggregate } \\
\text { Dimensions }\end{array}$ & $\begin{array}{c}\text { Second } \\
\text { Order Themes }\end{array}$ & $\begin{array}{l}\text { First Order } \\
\text { Categories }\end{array}$ & $\begin{array}{l}\text { Theoretical } \\
\text { Underpinning }\end{array}$ & HRM Practices & $\begin{array}{c}\text { Type } \\
\text { and Contexts }\end{array}$ & Examples \\
\hline & & $\begin{array}{l}\text { HRM } \\
\text { professionals } \\
\text { ought to protect } \\
\text { both } \\
\text { organizations and } \\
\text { their workers. }\end{array}$ & Review. & $\begin{array}{l}\text { Compensation } \\
\text { and benefits. }\end{array}$ & Review & [65] \\
\hline & & $\begin{array}{l}\text { Economic } \\
\text { hardships. } \\
\text { Furlough policy. } \\
\text { Perception of } \\
\text { fairness. }\end{array}$ & $\begin{array}{l}\text { Equity theory } \\
\text { and social } \\
\text { exchange theory. } \\
\text { Organizational } \\
\text { justice. } \\
\text { Psychological } \\
\text { contract. }\end{array}$ & $\begin{array}{l}\text { Turnover } \\
\text { intentions. } \\
\text { Procedural } \\
\text { justice/duration } \\
\text { of furlough. }\end{array}$ & $\begin{array}{l}\text { USA: mixed, } \\
\text { quantitative } \\
\text { followed by } \\
\text { follow-up content } \\
\text { analysis. }\end{array}$ & [66] \\
\hline & & $\begin{array}{l}\text { HR responses to } \\
\text { employee- } \\
\text { organization } \\
\text { relation during } \\
\text { COVID-19. }\end{array}$ & $\begin{array}{l}\text { Relational capital. } \\
\text { Person- } \\
\text { environment fit. } \\
\text { Work-life balance. } \\
\text { Pyramid of CSR. }\end{array}$ & $\begin{array}{l}\text { Remote work. } \\
\text { Safe working } \\
\text { conditions. } \\
\text { Adjustment to } \\
\text { Performance } \\
\text { management and } \\
\text { compensation. } \\
\text { Suspension of } \\
\text { dismissals. } \\
\text { Online HR } \\
\text { practices. } \\
\text { Emotional and } \\
\text { mental support. }\end{array}$ & $\begin{array}{l}\text { Poland: desktop } \\
\text { research. } \\
\text { US: quantitative, } \\
\text { survey from } \\
\text { forty-eight } \\
\text { organizations. }\end{array}$ & {$[49,67,68]$} \\
\hline & $\begin{array}{l}\text { Enable scholars to } \\
\text { envision new } \\
\text { HRM designs }\end{array}$ & $\begin{array}{l}\text { New COVID-19 } \\
\text { safe workplace } \\
\text { model. } \\
\text { New workplace } \\
\text { contract between } \\
\text { employer and } \\
\text { employee. } \\
\text { Talent } \\
\text { management. } \\
\text { Flexible work } \\
\text { arrangements } \\
\text { (FWAs). } \\
\text { 4-R } \\
\text { crisis-normalcy } \\
\text { model of HRD. } \\
\text { A new "normal." }\end{array}$ & $\begin{array}{l}\text { Workplace design } \\
\text { Talent } \\
\text { management } \\
\text { Professional work } \\
\text { Human resource } \\
\text { development }\end{array}$ & $\begin{array}{l}\text { Flexible work } \\
\text { Workplace design } \\
\text { WFH, succession } \\
\text { planning } \\
\text { Platform } \\
\text { economy } \\
\text { Technology } \\
\text { 4-R } \\
\text { crisis-normalcy } \\
\text { model (redefine, } \\
\text { relook, redesign } \\
\text { and } \\
\text { reincorporate) }\end{array}$ & Conceptual paper & {$[9,12,69-71]$} \\
\hline \multirow[t]{2}{*}{ Legitimizer } & \multirow[t]{2}{*}{$\begin{array}{l}\text { The pandemic } \\
\text { elevates the status } \\
\text { of certain } \\
\text { sustainable HRM } \\
\text { practices. } \\
\text { Highlight } \\
\text { sustainable HRM } \\
\text { and work- } \\
\text { place/employee. }\end{array}$} & $\begin{array}{l}\text { Broader } \\
\text { performance } \\
\text { outcomes. } \\
\text { Investigate the } \\
\text { influence of } \\
\text { socially } \\
\text { responsible } \\
\text { human resource } \\
\text { management } \\
\text { (SRHRM) on } \\
\text { employee fears of } \\
\text { external threats } \\
\text { during the } \\
\text { COVID-19 } \\
\text { outbreak. }\end{array}$ & $\begin{array}{l}\text { Socially } \\
\text { responsible HRM. } \\
\text { Social support } \\
\text { and event system } \\
\text { theories. } \\
\text { Paradox theory. }\end{array}$ & $\begin{array}{l}\text { Sustainable HRM } \\
\text { People-profit } \\
\text { paradox } \\
\text { Short vs. long } \\
\text { term paradox }\end{array}$ & $\begin{array}{l}\text { China: mixed } \\
\text { survey of } 408 \\
\text { employees in } \\
\text { hospitality and } \\
\text { tourism firms in } \\
\text { China } \\
\text { Conceptual }\end{array}$ & {$[8,25,72]$} \\
\hline & & $\begin{array}{l}\text { Employees' } \\
\text { Perception of } \\
\text { sustainable HRM } \\
\text { practices and } \\
\text { positive } \\
\text { organizational } \\
\text { behavior during } \\
\text { COVID-19. }\end{array}$ & $\begin{array}{l}\text { Social exchange } \\
\text { theory. }\end{array}$ & $\begin{array}{l}\text { HRM } \\
\text { involvement } \\
\text { perception. }\end{array}$ & $\begin{array}{l}\text { Quantitative, } \\
\text { self-report } \\
\text { questionnaire, } \\
\text { Italian workers }\end{array}$ & [55] \\
\hline
\end{tabular}




\section{COVID-19 as a Complicator}

Similar to its effect on employee wellbeing issues, COVID-19 plays a complicator role on HRM practices and systems, amplifying or diminishing the effect of some factors on certain HRM practices. For example, Xiao et al. [56] identified factors affecting the recruitment and retention of suitable care workers in aged care in Australia. COVID-19 infection and death rates amplified individual resistance to join the sector and lowered worker satisfaction, increasing turnover intention.

\section{COVID-19 as an Exposer}

COVID-19 exposed on a deeper level the problematic, even dystopian, nature of some of our core assumptions and theories in the HRM field, which amplify rather than moderate labor market inequality. Butterick and Charlwood [58] list two such examples, the flexible firm model [73] and the HR architecture model [74], both of which act as a propagator of labor commodification, the harmful effects of which on workers' wellbeing surfaced amidst COVID-19. Bapuji et al. [57] argued that organizational practices-CSR, work design, recruitment and selection, and compensation management-could contribute to the normalization, reinforcement and increase in economic inequalities in society. Exposing the insufficiencies of the HRM field is the first step towards correcting it; this could be the silver lining of COVID-19.

\section{COVID-19 as a Disrupter}

COVID-19 alters employees' normal experiences and relevant HRM practices. For example, Bajrami et al. [59] tests how different effects of COVID-19, expressed through job insecurity, employees' health complaints occurring during isolation, risk-taking behavior at workplaces and changes in the organization, may impact the work related attitudes (job motivation and job satisfaction) and turnover intentions of Serbian employees in the hospitality industry. Scott et al. [60] discusses how COVID-19 disrupted the normal onboarding procedures of organizations, proposing the three C's of onboarding (i.e., create structure, connect people and continue adapting) to ensure effectiveness. McFarland et al. [61] studies the impact of the COVID-19 pandemic on job search behavior using an event transition perspective and finds that the onset of the pandemic created an immediate increase in job search behavior (job applications), and this effect endured into the post onset period. These studies have provided insights into the disruptive effect COVID-19 had on the HRM practices and employees' experiences of them.

\section{COVID-19 as an Enabler (Both Positive and Negative)}

COVID-19 has enabled organizations to put into place new HRM policies and employee wellbeing programs, in addition to enabling scholars to envision a future HRM design (e.g., [9,12,69]. Specifically, COVID-19 has enabled a series of positive HRM practices to curb the adverse impact of COVID-19, including workplace guidelines and support, access to financial benefits and pandemic information (e.g., [63]), as well as remote work, safe working conditions, performance management and compensation adjustments, suspension of dismissals, online HR practices, and emotional and mental support (e.g., [49,67]), which, in turn, positively influence employee retention [63]. However, it also enabled economic hardships, furlough policies and the perception of injustice, which contribute to employees' turnover intentions (e.g., [66]). Conceptually, COVID-19 has raised discussion of the responsibilities of HRM professionals and necessary interventions, such as minimum wage adjustment, work week hours, compensation and benefits philosophy, etc. [65]. Przytuła et al. [64] reviews COVID-19's impact on HR practices such as recruitment and selection, remote working, motivating employees, reskilling and communicating. They identify the biggest challenges after COVID-19 for HR to be restructuring the place of work and the content of work, and applying more advanced technology to recruitment, selection and performance. 
COVID-19 stimulates scholars to envision new HRM designs in the context of COVID19 or after it, including COVID-19 safe workplace model, new workplace contracts between employer and employee (e.g., [69]) and other talent management issues (e.g., WFH, succession planning, platform economy, technology) [12]. Arora and Suri [71] analyze Indian organizations' responses to the pandemic and proposed a 4-R crisis-normalcy model for HRD professionals to address the challenges post-COVID-19. Bierema [75] challenges HRD scholars and practitioners to imagine how HRD might create a new normal through a bold, critical research inquiry that interrogates exclusion, pursues organizational and social justice, and creates humanly sustainable organizations and communities.

\section{COVID-19 as a Legitimizer}

COVID-19 has brought legitimacy to certain HRM practices and/or highlighted sustainable HRM and positive employee outcomes. For example, socially responsible HRM (one way of conceptualizing sustainable HRM) was found to negatively impact employee fears during the pandemic [25]. Sustainable HRM is positively related to organizational engagement and to extra role behavior [55]. These few empirical studies establish a link between sustainable HRM and employee outcomes and, thus, lend credibility to sustainable HRM.

\subsubsection{COVID-19's Impact on Sustainable Careers}

The literature on the career implications of COVID-19 $(n=6)$ reflects the "CEDE" components of the "CEDEL" model. Two out of these six studies are empirical in nature, both quantitative. Hospitality, university and tourism sectors are the preferred industry contexts. They all draw heavily from sustainable career/employment/development literature. See Table 5 for a summary.

Table 5. Impact of COVID-19 on sustainable career.

\begin{tabular}{|c|c|c|c|c|c|}
\hline $\begin{array}{c}\text { Aggregate } \\
\text { Dimensions }\end{array}$ & Second Order Themes & First Order Categories & $\begin{array}{l}\text { Theoretical } \\
\text { Underpinning }\end{array}$ & Type and Contexts & Examples \\
\hline Complicator & $\begin{array}{l}\text { Future of careers such } \\
\text { as people's willingness } \\
\text { to be health care } \\
\text { providers (more eager } \\
\text { or more hesitant). } \\
\text { Obscured boundaries } \\
\text { at the work-family } \\
\text { interface. }\end{array}$ & $\begin{array}{l}\text { Challenges and } \\
\text { changes to careers } \\
\text { post-COVID- } 19 .\end{array}$ & $\begin{array}{l}\text { Career shock. } \\
\text { Resilience. } \\
\text { Sustainable careers. } \\
\text { HRD. }\end{array}$ & Viewpoint paper. & {$[48,76]$} \\
\hline Exposer & $\begin{array}{l}\text { Job crafting contributes } \\
\text { to employee's } \\
\text { sustainable } \\
\text { employability due to } \\
\text { COVID-19. } \\
\text { Skill gap in tourism } \\
\text { and hospitality } \\
\text { industry. } \\
\text { Pervasive employment } \\
\text { disparities. }\end{array}$ & $\begin{array}{l}\text { Explore how } \\
\text { employers' investments } \\
\text { through job } \\
\text { characteristics engage } \\
\text { employees in job } \\
\text { crafting behaviors that } \\
\text { lead to sustainable } \\
\text { employability through } \\
\text { a motivational process } \\
\text { and accumulation of } \\
\text { job resources. } \\
\text { Addressing skills group } \\
\text { in Welsh tourism and } \\
\text { hospitality industry to } \\
\text { highlight importance of } \\
\text { sustainable tourism } \\
\text { development } \\
\text { post-COVID-19. }\end{array}$ & $\begin{array}{l}\text { Job } \\
\text { demands-resources } \\
\text { theory. } \\
\text { Sustainable } \\
\text { employability. } \\
\text { Sustainable } \\
\text { development. }\end{array}$ & $\begin{array}{l}\text { Pakistan: Punjab, } \\
\text { quantitative, } \\
\text { healthcare and } \\
\text { universities. } \\
\text { UK, Wales: } \\
\text { quantitative, survey } \\
\text { tourism and } \\
\text { hospitality industry. }\end{array}$ & {$[77,78]$} \\
\hline
\end{tabular}


Table 5. Cont.

\begin{tabular}{|c|c|c|c|c|c|}
\hline $\begin{array}{c}\text { Aggregate } \\
\text { Dimensions }\end{array}$ & Second Order Themes & First Order Categories & $\begin{array}{l}\text { Theoretical } \\
\text { Underpinning }\end{array}$ & Type and Contexts & Examples \\
\hline Disruptor & $\begin{array}{l}\text { Widespread } \\
\text { unemployment. } \\
\text { Worker mental health } \\
\text { threat. } \\
\text { Employment certainty. }\end{array}$ & $\begin{array}{l}\text { Investigated the } \\
\text { impacts of the } \\
\text { pandemic on four } \\
\text { distinct but related } \\
\text { domains of } \\
\text { employment and } \\
\text { offered policy } \\
\text { recommendations for } \\
\text { career development } \\
\text { professionals. }\end{array}$ & $\begin{array}{l}\text { Work-family } \\
\text { interface. } \\
\text { Workplace inequality }\end{array}$ & Viewpoint paper & [76] \\
\hline Enabler & $\begin{array}{l}\text { Workplace } \\
\text { configuration (to } \\
\text { accommodate social } \\
\text { distancing); push to } \\
\text { automate. } \\
\text { Certain psychological } \\
\text { resources-such as } \\
\text { career competencies } \\
\text { and resilience-could } \\
\text { make COVID-19 as } \\
\text { career shock more } \\
\text { manageable. } \\
\text { Differential } \\
\text { implications over time } \\
\text { (short-term vs. } \\
\text { long-term; across life } \\
\text { and career stages). } \\
\text { Pandemic, further into } \\
\text { the future it may allow } \\
\text { for more positive } \\
\text { outcomes (e.g., } \\
\text { upgrade skills and } \\
\text { competencies). } \\
\text { Sustainable career (the } \\
\text { process used to attract, } \\
\text { support and retain } \\
\text { employees in a way } \\
\text { that results in } \\
\text { committed and loyal } \\
\text { employees). }\end{array}$ & $\begin{array}{l}\text { Understand career } \\
\text { consequences of } \\
\text { COVID-19 using career } \\
\text { shocks literature and } \\
\text { offer research } \\
\text { suggestions. } \\
\text { Propose the concept of } \\
\text { sustainable } \\
\text { employment (SE) } \\
\text { against the background } \\
\text { of the COVID-19 } \\
\text { pandemic and give } \\
\text { insights into adopting } \\
\text { it/implementing it in } \\
\text { the (hospitality } \\
\text { industry) in the USA. }\end{array}$ & $\begin{array}{l}\text { Career shocks. } \\
\text { Sustainable career. }\end{array}$ & $\begin{array}{l}\text { Editorial. } \\
\text { Viewpoint paper. } \\
\text { USA: hospitality } \\
\text { industry. }\end{array}$ & {$[48,79,80]$} \\
\hline
\end{tabular}

\section{COVID-19 as a Complicator}

COVID-19 complicates the trends of future careers. Specifically, it is difficult to gauge whether people's willingness to be health care providers will increase due to the importance of such roles during COVID-19 or will decrease as they witness higher rates of infection and deaths with these roles [48]. Similar to the aforementioned complicating effect of COVID-19 on the discussion of the benefits and drawbacks of working from home (WFH), COVID-19 was said to have obscured boundaries at the work-family interface [76], which has implications for the future of careers.

\section{COVID-19's as an Exposer}

COVID-19 exposed pervasive employment disparities along the dimensions of race, gender and social class. For example, many people performing services deemed "essential" are often underpaid and treated as expendable, whilst white collar workers have been able to work from home (e.g., [76]). COVID-19 exposed that job crafting contributes to employee's sustainable employability due to COVID-19 [77]. It also exposed the skills gap in the tourism and hospitality industry, and highlights the importance of sustainable tourism development in post-COVID-19 recovery [78]. Similar to its exposing effect on the 
HRM field, COVID-19's role as an exposer of global employment and career landscapes have policy and practice implications for the career development of professionals.

\section{COVID-19 as a Disrupter}

COVID-19 caused widespread unemployment and employment uncertainty, and posed a mental health threat to workers [48,76]. It is also predicted to have differential implications over time (short term vs. long term; across life and career stages) [79]. This disrupting effect of COVID-19 on employment and career is self-evident.

\section{COVID-19 as an Enabler}

COVID-19 enables an array of career consequences from a career shocks perspective, and career competencies and resilience could make COVID-19 as a career shock more manageable. Further into the future, it may allow for more positive outcomes (e.g., the upgrading of skills and competencies) [79]. COVID-19 enables workplace configuration to accommodate social distancing; it pushes organizations to automate, impacting the career paths of some employee groups [48]. It also enables the adoption of the concept of sustainable careers in the hospitality industry in the USA [80]. Similar to its enabling of HRM practices, COVID-19 also enables new career paths or a reconfiguration of present career responsibilities.

\subsubsection{COVID-19 and CSR}

The last theme within the social pillar of sustainable HRM is concerned with COVID-19's impact on CSR $(n=3)$. The social responsibilities of a firm entails its impacts on society and the wellbeing of individuals and communities [81]. Charitable partnerships, employees' mental health and wellbeing, social equity, and community relations are examples of firm social responsibility [82] and it is following this definition that we have classified CSR under the social sustainability dimension. The three articles categorized within this key dimension all identified COVID-19 as a legitimizer within our CEDEL model.

\section{COVID-19 as the Legitimizer}

Three articles link the COVID-19 pandemic with CSR. All point to the legitimizing effect of COVID-19 on CSR, as this unusual public health crisis has firmly enhanced the importance of CSR to organizations. In particular, He and Harris [83] argue that the COVID-19 pandemic accelerates post-pandemic CSR development in the long run, if firms want to achieve long term survival. Aguinis, Villamor and Gabriel [84] focus on employees' experiences of CSR, or behavioral CSR, and discuss in the context of the COVID19 pandemic how Amazon's well intentioned CSR initiatives encountered backlash from its employees over lack of protection during implementation. Calls were made for more future research on behavioral CSR and COVID-19. Filimonau, Derqui and Matute [85] report that the COVID-19 pandemic highlights the importance of CSR of hotels as "duty of care" providers for its stakeholders, and past CSR practices up taken by hotels influence senior hotel managers' perceived job security and organizational commitment.

\subsection{COVID-19 and Environmental Sustainability Green HRM}

Compared with the social dimension of the sustainable HRM and COVID-19 nexus, the environmental sustainability of HRM and COVID-19 interface yields much less scholarly attention in the literature. Our review found only three articles, consisting of a literature review article on green HRM [28], and two empirical articles set in China [27] and Bahrain [86], respectively. The roles of COVID-19 are reflective of the "CE" components of the CEDEL model. 


\subsubsection{COVID-19 as a Complicator}

The COVID-19 pandemic has, understandably, brought the economic survival (economic dimension) as well as employee wellbeing issues (social dimension) of organizations' sustainability to the forefront, which begs the question: is the importance of green HRM (that is, the environmental dimension of sustainability) relegated by the COVID-19 or reinvigorated? Paulet et al. [28] undertook a meta-review of green HRM literature and concluded that COVID-19 had a "myriad of far-reaching implications, many of which are still unknown" (p. 20). Therefore, COVID-19 complicates the field of green HRM, representing either a roadblock or an opportunity for revitalization [28]. Similarly, Zhang et al.'s [27] empirical study explores the question of whether environmental sustainability took a backseat after COVID-19. It found that the ownership types of companies in China influenced the priorities of sustainability during COVID-19. Further, it indicated that economic sustainability is highly likely to be in the dominant position post-COVID-19 for all types of businesses, which leaves environmental sustainability neglected. This potentially creates a "post pandemic environmental rebound effect"; that is, the potential loss of pre-pandemic environmental improvements, with indicators such as air quality and greenhouse gas emissions potentially vanishing post-pandemic as this rebound effect takes over $[87,88]$.

\subsubsection{COVID-19 as an Exposer}

COVID-19 exposes the relationship dynamics among green HRM, green supply chain and firm performance. AlZgool et al. [86] examined the relationships between green HRM, green supply chain (SC) and firm performance in the food industry in Bahrain during the COVID-19 lockdown. Green HRM was exposed to have a direct and positive effect on firm performance, and the COVID-19 lockdown a negative role in the firm performance of food supply companies, and a negative moderating role between green SC and firm performance.

\subsection{COVID-19 and the Economic Dimension of HRM Sustainability}

To address the question of how, in the literature, the COVID-19 pandemic has influenced the economic dimension of HRM sustainability, we need to first clarify the relationships among the economic, environmental and social dimension of HRM sustainability, and what counts as the economic dimension. Ehnert, Harry and Zink's [89] work in sustainable HRM proposed three relationship dynamics among the three dimensions. First, economic, environmental and social are all equally important pillars. Second, economic sustainability is the paramount, with social and environmental ultimately serving the economic purpose. Third, environmental sustainability provides the ecological foundation upon which economic and social sustainability are possible.

\section{COVID-19 as an Enabler}

Adopting the first conceptualization of the economic dimension, we have located only one article that empirically linked organizations' human resource management policies and practices in the context of COVID-19 with discussion of its firm performance. In this conceptual paper [90], the role of COVID-19 is one of an enabler, as organizations tackle the issue of how to design SMART teamwork to boost performance in virtual teams following the challenges of COVID-19. We have yet to locate articles that explore sustainable HRM practices in the context of COVID-19 with financial performance indicators such as share price, return on investment (ROI) and return on assets (ROA), examples of often popular outcome variables in HRM research [91]. The dearth of research in this domain indicates that scholars take it as self evident that there is a negative correlation between COVID-19 and organizational financial performances on a broad scale [92]. Another reason is the effect of the COVID-19 pandemic on the economic dimension of HRM sustainability is myriad and lingering, hence making the measurability issue difficult for scholars. Nevertheless, our review indicates a lacuna in the economic rationale of sustainable HRM at the COVID19 and sustainable HRM nexus, contrary to the HRM performance foci of the strategic HRM field. 
If we follow the second and/or the third relationship dynamics (i.e., economic sustainability as encompassing social and environmental sustainability, or economic sustainability as a part of environmental sustainability), then it could be argued that our conceptualization of COVID-19's impact on social and environmental dimension of HRM sustainability is also applicable to the economic dimension of HRM sustainability. That is to say, COVID-19 has brought employees' wellbeing issues amidst COVID-19 to the forefront (complicating, exposing, disrupting), shaped sustainable HRM policies (enabling, complicating, exposing and disrupting), legitimized CSR and raised the discussion on the importance of green HRM in the COVID-19 era. These, overall, exert an impact on the economic survival of the organizations.

\section{Future Research Avenues}

Our review has discussed the contributions as well as the gaps in research at the intersection of COVID-19 and sustainable HRM. In the following section, we articulate several possible avenues for future research in light of these gaps, categorized as definitional and thematic avenues.

\subsection{Definitional Avenues}

First, our review has highlighted a lack of conceptual clarity surrounding the concepts of sustainable HRM. This presents no surprise, as the field of sustainable HRM has long been plagued with definitional ambiguity as different approaches were adopted. Some of the articles reviewed explicitly stated a definition for sustainable HRM (e.g., [25,55]), in alignment with one of the four said approaches, whereas others were merely implied (e.g., [26,36,37]). Future research on COVID-19 and sustainable HRM needs to: (1) explicitly articulate a definition of sustainable HRM; and (2) operationalize sustainable HRM in a holistic manner. Better understanding of COVID-19 and sustainable HRM integration requires scholars to reach agreement about what these constructs mean exactly, and, consequently, fill out the missing pieces to create a holistic and coherent conceptual map to guide future generations, scholars and HR practitioners alike. To this end, the literature review article by Aust et al. [1] is a good step in the right direction, as the authors compare four approaches to sustainable HRM and recommend the conceptualization of sustainable HRM as the common good HRM for future research. We argue the triple bottom line approach to sustainable HRM will continue to be useful. However, against the backdrop of the COVID19 pandemic, it appears that our battle against a global pandemic falls neatly within the remit of "common good," as individuals, organizations and societies come together to solve this "grand" sustainability challenge for all. Hence, future research is needed that explores the impact of COVID-19 on sustainable HRM when the latter is operationalized as common good HRM.

\subsection{Thematic Avenues}

\subsubsection{Along the Dimensions of Our Framework}

Our review article yielded a five dimension framework-the CEDEL model-that contextualizes the effect of COVID-19 on sustainable HRM in the literature. We suggest future research can be guided by the knowledge gaps identified along each dimension of this framework. Table 6 proposes a series of specific research questions that could ignite this further inquiry process. 
Table 6. Thematic research avenues for COVID-19 on sustainable HRM.

\begin{tabular}{ll}
\hline $\begin{array}{c}\text { COVID-19's Effect on } \\
\text { Sustainable HRM }\end{array}$ & \multicolumn{1}{c}{ Future Research Avenues } \\
\hline & $\begin{array}{l}\text { Does COVID-19 and its associated aftermath intensify } \\
\text { employees' work-life conflicts or does it mitigate the } \\
\text { conflicts? Is this complicating effect mediated by } \\
\text { factors such as gender, profession, organization, } \\
\text { marital and children status or even country contexts? } \\
\text { In the post-pandemic era, should organizations retain } \\
\text { sovID-19 as a complicator }\end{array}$ \\
& $\begin{array}{l}\text { solicies or should they revert to the old ways? Before } \\
\text { research reaches a conclusion, how should } \\
\text { organizations innovatively embed working from home } \\
\text { policies in their HRM strategy to achieve economic } \\
\text { and social sustainability? }\end{array}$ \\
\hline
\end{tabular}

COVID-19 has exposed some instances of workplace inequalities and injustices. Based on our review, there is a need for an integrated framework that systematically maps out how employees of different demographics (gender, age, race, social class, skills, etc.) and industries could be impacted by public health crises such as a global pandemic. More importantly, how could these pandemic induced inequalities be pre-empted or addressed to achieve the ultimate goal of the sustainable development of human resources? McGuire et al.'s [33] ethics of care

COVID-19 as an exposer approach offers a starting point; future scholars could explore how the ethics of care theory could be incorporated into sustainable HRM strategy and practices. Going beyond a firm level, Bansal et al. [7] suggest a systems perspective to understand the implications of COVID-19 on business and society. We argue that other leadership, ethical, sociological theories present opportunities for the cross fertilization of ideas and potential for sustainable HRM to grow rapidly as a field post-pandemic. In particular, sustainable HRM as common good HRM [1] seems to fit this purpose better.

There seems to be assumed knowledge in this regard. Apart from a few studies (e.g., $[60,61])$, there is a lack of empirical research on COVID-19's disrupting effect on sustainable HRM strategies and practices. Future scholars could explore how COVID-19 disrupted organizational sustainable HRM agendas beyond the themes covered in this review, namely, job search and onboarding, the person-environment fit of employees,

COVID-19 as a disruptor sociopsychological wellbeing [46], normal working conditions [59], and employees' experiences of HRM practice (e.g., [60]). From a context perspective, research efforts could extend beyond the healthcare industry to look at banking and finance, retail, hospitality, tourism, education, etc., to gain a holistic understanding. Longitudinal studies would also be useful to help us understand the shorter and longer term effect of COVID-19. 
Table 6. Cont.

\begin{tabular}{|c|c|}
\hline $\begin{array}{l}\text { COVID-19's Effect on } \\
\text { Sustainable HRM }\end{array}$ & Future Research Avenues \\
\hline COVID-19 as an enabler & $\begin{array}{l}\text { There are fragmented research efforts that look at } \\
\text { COVID-19's enabling effect of new HRM } \\
\text { policies/practices such as employee retention, } \\
\text { compensation and benefits, furlough policies, } \\
\text { emotional support policies and performance } \\
\text { management. There lacks, overall, an integrated and } \\
\text { comprehensive framework that uncovers COVID-19 } \\
\text { induced HRM responses. For example, how has } \\
\text { COVID-19 enabled other innovative HRM practices } \\
\text { associated with recruitment and selection, training and } \\
\text { development remains unknown (other than the } \\
\text { practices have gone virtual). In addition, COVID-19's } \\
\text { enabling effect on sustainable HRM strategies and } \\
\text { practices could be both positive and negative. The } \\
\text { literature is tilted towards capturing the positive } \\
\text { examples of a few organizations making sensible } \\
\text { adjustments (e.g., [68]). The dark side of COVID-19 as } \\
\text { an enabler of unsustainable or unbecoming HRM } \\
\text { policies remains underexplored, though there are } \\
\text { media report of disheartening examples of employer } \\
\text { surveillance of remote workers using tracking } \\
\text { software known as "tattleware" [93] or the compulsory } \\
\text { installment of spyware (e.g., Hubstaff) on their } \\
\text { computers while working from home. We need } \\
\text { empirical studies to shed light on this negative } \\
\text { enabling effect of COVID-19 on sustainable HRM } \\
\text { practices in order to avoid making similar mistakes in } \\
\text { the future. }\end{array}$ \\
\hline COVID-19 as a legitimizer & $\begin{array}{l}\text { The extant literature on the relationship between } \\
\text { sustainable HRM practices and employee and/or } \\
\text { organizational outcomes in the backdrop of COVID-19 } \\
\text { is very limited. Two empirical studies were found to } \\
\text { bridge this gap, and legitimize sustainable HRM. For } \\
\text { example, there is a negative relationship between } \\
\text { socially responsible HRM (a conceptualization of } \\
\text { sustainable HRM) and employee fears during the } \\
\text { pandemic [25] and a positive relationship between } \\
\text { HRM involvement perception to organizational } \\
\text { engagement and extra role behavior [55]. Similarly, } \\
\text { there is research evidence for the legitimizing effect of } \\
\text { COVID-19 on CSR. These studies offer preliminary } \\
\text { substantiating evidence that sustainable HRM is more } \\
\text { than a fad. In what other ways are sustainable HRM } \\
\text { strategies and practices related to employee and } \\
\text { organizational outcomes constitutes fertile ground for } \\
\text { future research. }\end{array}$ \\
\hline
\end{tabular}

\subsubsection{Beyond Our Framework}

"By its essence, COVID-19 is a threat to the health and safety of employees requiring organizations to evaluate employee risk" [8] (p. 3). Consequently, we see employees being given elevated consideration as a critical stakeholder group in the COVID-19 related sustainable HRM literature. Albeit commendable in its efforts to incorporate dimensions of diversity (e.g., gender, race, marriage status, employment mode) when employees were studied, this conceptualization of sustainable HRM is still not genuinely reflective of the multiple stakeholder perspective the field advocates for [94,95]. In practice, the impacts of COVID-19 on organizations are complex, multidimensional, profound and 
multilayered. Effective and innovative COVID-19 responses or ineffective strategies alike have the potential to offer us valuable lessons. We recognize the value of the employee focused nature of the current literature on COVID-19 and sustainable HRM, but argue that a wider research agenda is needed to acknowledge the role of all relevant stakeholder groups and HRM's mission in spearheading this "sustainability paradigm shift" [96] (p. 129). Hence, we recommend that the academic community in the sustainable HRM field need to "play catch up" and examine the impact of COVID-19 on sustainable HRM from a wider, more contextual and more multilayered approach that addresses the needs of multiple stakeholders, including not only employee groups of all backgrounds, but also customers, shareholders, management, government, community, unions, civil society, etc. Collings et al. [8], for example, highlighted the lack of research attention to customers as stakeholders in HR research, despite calls for their consideration [95]. They point out that future research needs to consider how HR practices need to be modified to account for shifts in service delivery. Echoing their research calls, we suggest future research could explore implications for HR professionals of their organizations' digitalization and COVID19 safe service delivery. Similarly, how has the effect of COVID-19 influenced/challenged the role of trade unions or the dynamics among the government, the unions and other stakeholder groups?

Additionally, our review has highlighted a dearth of research linking sustainable HRM to organizational performance during COVID-19. This is perhaps explainable by the noneconomic focus of sustainable HRM $[89,97]$, which originated from the basis of the critique of economic dominance of the strategic HRM field. Hence, it seems paradoxical to suggest future research examine the relationship between sustainable HRM and the economic performances of organizations in the backdrop of COVID-19. However, sustainable HRM, though critical of the traditional profit driven HRM models, does not deny the importance of organizational economic sustainability. It follows naturally that exploring the links between the two is a necessary component in its course of development. Circumventing or omitting economic sustainability is not reflective of the tenets of the sustainable HRM field. In addition, sustainable HRM is at the stage of garnering attention as well as scholarly and practical legitimacy, if taking a step back (restoring to a study of economic rationality characteristics of traditional HRM models) means taking two steps forward (sustainable HRM development gaining momentum), it is no doubt progress, or as Beer et al., [95] neatly termed, "back to the future". Underpinned by this reasoning, future research could investigate: (1) how sustainable HRM strategies and practices during the COVID-19 pandemic (e.g., recruitment of employees who have knowledge and experience of social and environmental sustainability; inclusion of sustainability objectives into performance management and reward systems) could contribute to the organization's performance over the long term; and (2) following Kramar's [72] call for a broader conception of performance outcomes for organizations following COVID-19, sustainable HRM post-pandemic could explore how to incorporate sustainability into the economic dimensions, either manifested into SDG goals, and/or International Labor Organization Declarations and Initiatives and so forth.

Lastly, our review identified the need for future research to shed more light on the environmental dimension of HRM and COVID-19 interface, also known as green HRM and COVID-19. The few articles there are piqued readers' curiosity about the status of green HRM during and after COVID-19, but more questions than answers were generated. Did green HRM take a backseat during COVID-19 to the economic and social sustainability of HRM or did it get a status boost? What factors are at play? How can HRM prepare for the post-pandemic environmental rebound effect $[87,88]$ ? How is green HRM linked with organizational performances during and/or after COVID-19? What are the mediators? Green HRM and COVID-19 constitute fertile group for future research. 


\subsection{Methodological Avenues}

Among the 56 articles, only $45 \%$ were empirical in nature $(n=25), 55 \%(n=31)$ are either review papers, conceptual papers or viewpoint papers. Overall, there is a lack of empirical studies. This could be partially explained by the fact that COVID-19's impact is ongoing, and/or the difficulty in data collection associated with various lockdown measures. We encourage future researchers to be resourceful and undertake COVID-19 safe approaches to gather data from the field to uncover, with a joint effort, the trends of sustainable HRM under the influence of COVID-19.

Within the 25 empirical papers, the majority of the studies adopted either a mixed method approach or a purely quantitative design, with only 4 utilizing qualitative methods. This represents a missed opportunity to uncover valuable in depth insights, as qualitative approaches are more adept at addressing contexts and underlying "how" and "why" questions [98]. As the review reveals, the effect of COVID-19 is context bound, subject to the organizational, industry and national contexts, the role COVID-19 plays in sustainable HRM agenda varies, and qualitative research utilizing a myriad of methods can complete the puzzle jointly. In addition to semi-structured interviews, focus groups with HR mangers and practitioners, CSR managers, general managers etc., as well as participant observation approaches, and, if circumstances allow, longitudinal case study approaches, should be mobilized by future researchers. Hence, future research is recommended to explore the COVID-19-sustainable HRM interface using a mix of methods not limited to case studies, longitudinal case/survey research, action research or mixed methods.

A small number of the extant literature has sampled a few geographic regions of the world, and virtually no studies are comparative across different societal contexts. We need more in depth comparative studies to understand the contextual differences of the COVID-19-sustainable HRM interface between the East and the West, and to identify variations, if any, in their approach to sustainable HRM amid COVID-19. In addition, the industries concentrated on healthcare, tourism, hotel, and higher education. HRM is identified to be the most localized of management practices $[99,100]$, though there is emerging evidence that countries are becoming more alike in the way they conceive of and manage senior executives of multinational firms [101,102]. Does this knowledge apply to sustainable HRM? If so, how do national characteristics account for the variances in sustainable HRM practices? Has COVID-19 influenced the conception, implementation and future development of sustainable HRM strategy/practices in a more localized manner, or in a standardized manner? What situational factors are at play? Further, different countries are at different stages of pandemic containment; how did the variances in COVID-19 control influence the different dimensions of sustainable HRM? In order to further uncover the impact of COVID-19 on sustainable HRM in a truly contextualized manner, future research needs to widen the geographical span, industry boundaries and COVID-19 coverage, using cross national comparative studies to clarify the exact effect this global pandemic has had across nations on sustainable HRM.

\section{Limitations}

Though making significant contributions to the relevant literature, our review has its own limitations. First, by focusing on peer reviewed journal articles published in English, we acknowledge that we may have missed relevant studies presented in other outlets and written in other languages addressing the same topic of interest. We hope this review could stimulate future scholars to join and continue this "current conversation" by including more sources in multiple languages, such as books, reports, newspaper articles and other non-peer-reviewed publications. Second, guided by the research purpose (i.e., exploring the impact of COVID-19 on sustainable HRM), the articles on sustainable HRM we searched and included had to contain "COVID-19" (and its variant forms of expression). This deems potential studies on sustainable HRM published prior to the outbreak of COVID-19 beyond our scope of interest. Though the approach we took is informed by the research purpose, and we have nevertheless drawn on prior seminal work [2,4] on sustainable HRM for 
the non-COVID-19 part of the analysis, we wonder whether the excluded literature on sustainable HRM might add anything to our analysis. We therefore encourage scholars to compare sustainable HRM prior to, during and, hopefully soon, post-COVID-19 to examine the same issue from a different angle (by utilizing more comprehensive inclusion criteria for articles) and improve upon our findings. Last, the construction of the CEDEL model is novel, and has explanatory power, but is likely to be incomplete due to the ongoing twists and turns in the development of the pandemic. Hence, our theoretical framework might be "malleable" in nature in light of new evidence to be found. Despite these limitations, the findings our review generates lay groundwork for future researchers to further theorize the impact of COVID-19 on various disciplines.

\section{Conclusions}

Drawing on 56 conceptual and empirical articles published after the COVID-19 pandemic outbreak in English language, peer reviewed journals, our review paper explores how the nexus between COVID-19 and sustainable HRM has been addressed by the management community. We conceptualized our CEDEL model consisting of five types of effects COVID-19 has on the sustainable HRM literature (i.e., complicating, exposing, disrupting, enabling and legitimizing). We point out clear paths future researchers could take to further the development of sustainable HRM as rapidly growing fields post-pandemic. The ongoing impact of COVID-19 on sustainable HRM is very likely to extend far beyond the dimensions we have identified and as its effects unfolds. We hope future scholars are en route to theorizing beyond our CEDEL model.

Author Contributions: Conceptualization, X.L. and X.Z.; methodology, X.Z.; preliminary analysis, X.L.; formal analysis, X.L., X.Z., R.P. and L.J.Z.; investigation, X.L., X.Z., R.P. and L.J.Z.; data curation, X.L., X.Z., R.P. and L.J.Z.; writing-original draft preparation, X.L. and X.Z.; writing-review and editing, X.L., X.Z., R.P. and L.J.Z.; visualization, X.L. and X.Z.; project administration, X.L., X.Z., R.P. and L.J.Z. All authors have read and agreed to the published version of the manuscript.

Funding: This research received no external funding.

Institutional Review Board Statement: Not applicable.

Informed Consent Statement: Not applicable.

Data Availability Statement: Not applicable.

Conflicts of Interest: The authors declare no conflict of interest.

\section{References}

1. Aust, I.; Matthews, B.; Muller-Camen, M. Common Good HRM: A paradigm shift in Sustainable HRM? Hum. Resour. Manag. Rev. 2020, 30, 100705. [CrossRef]

2. Ehnert, I. Sustainable Human Resource Management: A Conceptual and Exploratory Analysis from A Paradox Perspective; Physica-Verlag: Dordrecht, The Netherlands, 2009.

3. Guerci, M.; Shani, A.; Solari, L. A stakeholder perspective for sustainable HRM. In Sustainability and Human Resource Management. Developing Sustainable Business Organisations; Ehnert, I., Harry, W., Zink, K.J., Eds.; Springer: Berlin/Heidelberg, Germany, 2014; pp. 205-224.

4. Kramar, R. Beyond strategic human resource management: Is sustainable human resource management the next approach? Int. J. Hum. Resour. Manag. 2014, 25, 1069-1089. [CrossRef]

5. Lopez-Cabrales, A.; Valle-Cabrera, R. Sustainable HRM strategies and employment relationships as drivers of the triple bottom line. Hum. Resour. Manag. Rev. 2020, 30, 100689. [CrossRef]

6. Stankevičiūtè, Ž.; Savanevičienè, A. Can sustainable HRM reduce work-related stress, work-family conflict, and burnout? Int. Stud. Manag. Organ. 2019, 49, 79-98. [CrossRef]

7. Bansal, P.; Grewatsch, S.; Sharma, G. How COVID-19 informs business sustainability research: It's time for a systems perspective. J. Manag. Stud. 2021, 58, 602-606. [CrossRef]

8. Collings, D.G.; McMackin, J.; Nyberg, A.J.; Wright, P.M. Strategic human resource management and COVID-19: Emerging challenges and research opportunities. J. Manag. Stud. 2021, 58, 1378-1382. [CrossRef]

9. Hoff, T. COVID-19 and The Study of Professionals and Professional Work. J. Manag. Stud. 2021, 58, 1395-1399. [CrossRef] 
10. Dyllick, T.; Muff, K. Clarifying the meaning of sustainable business: Introducing a typology from business-as-usual to true business sustainability. Organ. Environ. 2016, 29, 156-174. [CrossRef]

11. Haghani, M.; Bliemer, M.C. COVID-19 pandemic and the unprecedented mobilisation of scholarly efforts prompted by a health crisis: Scientometric comparisons across SARS, MERS and 2019-nCov literature. Scientometrics 2020, 125, 2695-2726. [CrossRef]

12. Vaiman, V.; Cascio, W.F.; Collings, D.G.; Swider, B.W. The shifting boundaries of talent management. Hum. Resour. Manag. 2021, 60, 253-257. [CrossRef]

13. Bush, J.T. Win-Win-Lose? Sustainable HRM and the promotion of unsustainable employee outcomes. Hum. Resour. Manag. Rev. 2020, 30, 100676. [CrossRef]

14. Podgorodnichenko, N.; Edgar, F.; McAndrew, I. The role of HRM in developing sustainable organizations: Contemporary challenges and contradictions. Hum. Resour. Manag. Rev. 2020, 30, 100685. [CrossRef]

15. Stahl, G.K.; Brewster, C.J.; Collings, D.G.; Hajro, A. Enhancing the role of human resource management in corporate sustainability and social responsibility: A multi-stakeholder, multidimensional approach to HRM. Hum. Resour. Manag. Rev. 2020, 30, 100708. [CrossRef]

16. Petticrew, M.; Roberts, H. How to appraise the studies: An introduction to assessing study quality. In Systematic Reviews in the Social Sciences: A Practical Guide; Blackwell Publishing: Hoboken, NJ, USA, 2006; pp. 125-163.

17. Denyer, D.; Tranfield, D. Producing a systematic review. In The SAGE Handbook of Organisational Research Methods, 2nd ed.; Buchanan, D.A., Bryman, A., Eds.; SAGE Publications Ltd.: New York, NY, USA, 2009; pp. 671-689.

18. Miles, M.B.; Huberman, A.M.; Salanda, J. Qualitative Data Analysis: A Methods Sourcebook; Sage Publications: New York, NY, USA, 2014.

19. Moher, D.; Liberati, A.; Tetzlaff, J.; Altman, D.G. Preferred reporting items for systematic reviews and meta-analyses: The PRISMA statement. PLoS Med. 2009, 6, e1000097. [CrossRef] [PubMed]

20. De Cieri, H.; Lazarova, M. "Your health and safety is of utmost importance to us": A review of research on the occupational health and safety of international employees. Hum. Resour. Manag. Rev. 2020, 31, 100790. [CrossRef]

21. Cooke, F.L.; Wood, G.; Wang, M.; Veen, A. How far has international HRM travelled? A systematic review of literature on multinational corporations (2000-2014). Hum. Resour. Manag. Rev. 2019, 29, 59-75. [CrossRef]

22. Donohue, J.M.; Fox, J.B. A multi-method evaluation of journals in the decision and management sciences by US academics. Omega 2000, 28, 17-36. [CrossRef]

23. Harzing, A.-W.; Alakangas, S. Google Scholar, Scopus and the Web of Science: A longitudinal and cross-disciplinary comparison. Scientometrics 2016, 106, 787-804. [CrossRef]

24. Miles, M.B.; Huberman, A.M. Qualitative Data Analysis: An Expanded Sourcebook, 2nd ed.; Sage Publications Inc.: New York, NY, USA, 1994.

25. He, J.; Mao, Y.; Morrison, A.M.; Coca-Stefaniak, J.A. On being warm and friendly: The effect of socially responsible human resource management on employee fears of the threats of COVID-19. Int. J. Contemp. Hosp. Manag. 2021, 33, 346-366. [CrossRef]

26. Raišienè, A.G.; Rapuano, V.; Varkulevičiūtè, K.; Stachová, K. Working from home-Who is happy? A survey of Lithuania's employees during the COVID-19 quarantine period. Sustainability 2020, 12, 5332. [CrossRef]

27. Zhang, D.; Hao, M.; Morse, S. Is environmental sustainability taking a backseat in China after COVID-19? The perspective of business managers. Sustainability 2020, 12, 10369. [CrossRef]

28. Paulet, R.; Holland, P.; Morgan, D. A meta-review of 10 years of green human resource management: Is Green HRM headed towards a roadblock or a revitalisation? Asia Pac. J. Hum. Resour. 2021, 59, 159-183. [CrossRef]

29. Ceular-Villamandos, N.; Navajas-Romero, V.; Caridad y López del Río, L.; Zambrano-Santos, L.Z. Workplace situation and well-being of ecuadorian self-employed. Sustainability 2021, 13, 1892. [CrossRef]

30. Almeida, F.; Santos, J.D. The effects of COVID-19 on job security and unemployment in Portugal. Int. J. Sociol. Soc. Policy 2020, 40, 995-1003. [CrossRef]

31. Warmate, Z.; Eldaly, M.K.; Elamer, A.A. Offering flexible working opportunities to people with mental disabilities: The missing link between sustainable development goals and financial implications. Bus. Strategy Environ. 2020, 30, 1563-1579. [CrossRef]

32. Hammer, E. HRD Interventions that offer a solution to work-life conflict. Adv. Dev. Hum. Resour. 2021, 23, 142-152. [CrossRef]

33. McGuire, D.; Germain, M.L.; Reynolds, K. Reshaping HRD in light of the COVID-19 pandemic: An ethics of care approach. Adv. Dev. Hum. Resour. 2020, 23, 26-40. [CrossRef]

34. Green, N.; Tappin, D.; Bentley, T. Working from home before, during and after the COVID-19 pandemic: Implications for workers and organisations. N. Zeal. J. Employ. Relat. 2020, 45, 5-16. [CrossRef]

35. Milliken, F.J.; Kneeland, M.K.; Flynn, E. Implications of the COVID-19 pandemic for gender equity issues at work. J. Manag. Stud. 2020, 57, 1767-1772. [CrossRef]

36. Bhattacharjee, S. 'Work from home' as an alternative to daily commuting for working women. Hum. Geogr. 2020, 14, 255-265. [CrossRef]

37. Mikołajczyk, K. Sustainable development of an individual as a result of mutual enrichment of professional and personal life. Sustainability 2021, 13, 697. [CrossRef]

38. Vaziri, H.; Casper, W.J.; Wayne, J.H.; Matthews, R.A. Changes to the work-family interface during the COVID-19 pandemic: Examining predictors and implications using latent transition analysis. J. Appl. Psychol. 2020, 105, 1073-1087. [CrossRef] [PubMed]

39. Davidescu, A.A.; Apostu, S.A.; Paul, A.; Casuneanu, I. Work flexibility, job satisfaction, and job performance among Romanian employees-Implications for sustainable human resource management. Sustainability 2020, 12, 6086. [CrossRef]

40. Agarwal, P. Shattered but smiling: Human resource management and the wellbeing of hotel employees during COVID-19. Int. J. Hosp. Manag. 2021, 93, 102765. [CrossRef] 
41. Chen, H.; Liu, F.; Pang, L.; Liu, F.; Fang, T.; Wen, Y.; Chen, S.; Xie, Z.; Zhang, X.; Zhao, Y.; et al. Are you tired of working amid the pandemic? The role of professional identity and job satisfaction against job burnout. Int. J. Environ. Res. Public Health 2020, 17, 9188. [CrossRef]

42. Jung, H.S.; Jung, Y.S.; Yoon, H.H. COVID-19: The effects of job insecurity on the job engagement and turnover intent of deluxe hotel employees and the moderating role of generational characteristics. Int. J. Hosp. Manag. 2021, 92, 102703. [CrossRef]

43. Jaškevičiūtè, V.; Stankevičienè, A.; Diskienè, D.; Savickè, J. The relationship between employee well-being and organizational trust in the context of sustainable human resource management. Probl. Perspect. Manag. 2021, 19, 118-131. [CrossRef]

44. Jooss, S.; McDonnell, A.; Conroy, K. Flexible global working arrangements: An integrative review and future research agenda. Hum. Resour. Manag. Rev. 2020, 31, 100780. [CrossRef]

45. Piwowar-Sulej, K.; Bak-Grabowska, D. Non-Permanent Employment and Employees' Health in the Context of Sustainable HRM with a Focus on Poland. Soc. Sci. 2020, 9, 117. [CrossRef]

46. Carnevale, J.B.; Hatak, I. Employee adjustment and well-being in the era of COVID-19: Implications for human resource management. J. Bus. Res. 2020, 116, 183-187. [CrossRef]

47. Ahmed, F.; Zhao, F.; Faraz, N.A. How and when does inclusive leadership curb psychological distress during a crisis? Evidence from the COVID-19 outbreak. Front. Psychol. 2020, 11, 1898-1911. [CrossRef] [PubMed]

48. Hite, L.M.; McDonald, K.S. Careers after COVID-19: Challenges and changes. Hum. Resour. Dev. Int. 2020, 23, 427-437. [CrossRef]

49. Ławrynowicz, M.; Marcinkowska, M. COVID-19 and the HR response of banks: The employee perspective. Hum. Resour. Manag. /Zarz. Zasobami Ludzkimi 2020, 137, 129-144.

50. Spurk, D.; Straub, C. Flexible employment relationships and careers in times of the COVID-19 pandemic. J. Vocat. Behav. 2020, 119, 103435. [CrossRef] [PubMed]

51. Dmitrieva, K.; Pickert, R.; Tanzi, A.; Sam, C. Next Wave of U.S. Job Cuts Targets Millions of Higher-Paid Workers. Bloomberg. Available online: https:/ / www.bloomberg.com/graphics/2020-how-many-more-jobs-will-be-lost/ (accessed on 3 June 2021).

52. Collings, D.G.; Nyberg, A.J.; Wright, P.M.; McMackin, J. Leading through paradox in a COVID-19 world: Human resources comes of age. Hum. Resour. Manag. J. 2021, 31, 819-833. [CrossRef]

53. Kristof-Brown, A.L.; Zimmerman, R.D.; Johnson, E.C. Consequences of individual's fit at work: A meta-analysis of person-job, person-organization, person- group, and person-supervisor fit. Pers. Psychol. 2005, 58, 281-342. [CrossRef]

54. Achor, S.; Kellerman, G.R.; Reece, A.; Robichaux, A. America's loneliest workers, according to research. Harv. Bus. Rev. 2018, 3, 2-6. Available online: https://hbr.org/2018/03/americas-loneliest-workers-according-to-research (accessed on 8 December 2021).

55. Manuti, A.; Giancaspro, M.L.; Molino, M.; Ingusci, E.; Russo, V.; Signore, F.; Zito, M.; Cortese, C.G. "Everything will be fine": A study on the relationship between employees' perception of sustainable HRM practices and positive organizational behavior during COVID-19. Sustainability 2020, 12, 10216. [CrossRef]

56. Xiao, L.D.; Harrington, A.; Mavromaras, K.; Ratcliffe, J.; Mahuteau, S.; Isherwood, L.; Gregoric, C. Care workers' perspectives of factors affecting a sustainable aged care workforce. Int. Nurs. Rev. 2020, 68, 49-58. [CrossRef]

57. Bapuji, H.; Patel, C.; Ertug, G.; Allen, D.G. Corona crisis and inequality: Why management research needs a societal turn. J. Manag. 2020, 46, 1205-1222. [CrossRef]

58. Butterick, M.; Charlwood, A. HRM and the COVID-19 pandemic: How can we stop making a bad situation worse? Hum. Resour Manag. J. 2021, 31, 847-856. [CrossRef]

59. Bajrami, D.D.; Terzić, A.; Petrović, M.D.; Radovanović, M.; Tretiakova, T.N.; Hadoud, A. Will we have the same employees in hospitality after all? The impact of COVID-19 on employees' work attitudes and turnover intentions. Int. J. Hosp. Manag. 2021, 94, 102754. [CrossRef] [PubMed]

60. Scott, C.P.; Dieguez, T.A.; Deepak, P.; Gu, S.; Wildman, J.L. Onboarding during COVID-19: Create structure, connect people, and continue adapting. Organ. Dyn. 2021, 2021, 100828. [CrossRef]

61. McFarland, L.A.; Reeves, S.; Porr, W.B.; Ployhart, R.E. Impact of the COVID-19 pandemic on job search behavior: An event transition perspective. J. Appl. Psychol. 2020, 105, 1207-1217. [CrossRef]

62. Minbaeva, D. Disrupted HR? Hum. Resour. Manag. Rev. 2020, 31, 100820. [CrossRef]

63. Elsafty, A.S.; Ragheb, M. The role of human resource management towards employees retention during COVID-19 pandemic in medical supplies sector-Egypt. Bus. Manag. Stud. 2020, 6, 5059. [CrossRef]

64. Przytuła, S.; Strzelec, G.; Krysińska-Kościańska, K. Re-vision of future trends in Human Resource Management (HRM) after COVID-19. J. Intercult. Manag. 2020, 12, 70-90. [CrossRef]

65. Abston, K.A.; Bryant, P.C. Compensation and benefits in a pandemic and post pandemic world: Introduction to compensation \& benefits review. Compens. Benefits Rev. 2021, 53, 3-7. [CrossRef]

66. Huffman, A.H.; Albritton, M.D.; Matthews, R.A.; Muse, L.A.; Howes, S.S. Managing furloughs: How furlough policy and perceptions of fairness impact turnover intentions over time. Int. J. Hum. Resour. Manag. 2021, 1-28. [CrossRef]

67. Gigauri, I. Organizational support to HRM in times of the COVID-19 pandemic crisis. Eur. J. Mark. Econ. 2020, 3, 36-48. [CrossRef]

68. Connell, C.M.; Lemyze, C.; McGill, W.L. The persistent link between growing talent and growing the top line: Lessons from fast-growing firms in the COVID-19 recession. Organ. Dyn. 2020, 50, 100807. [CrossRef]

69. O'Rourke, G.A. Workplace strategy: A new workplace model. Asia Pac. J. Hum. Resour. 2021, 59, 554-566. [CrossRef]

70. Waples, E.P.; Baskin, B.M.E. Not Your Parents' Organization? Human Resource Development Practices for Sustainable Flex Work Environments. Adv. Dev. Hum. Resour. 2021, 23, 153-170. [CrossRef] 
71. Arora, P.; Suri, D. Redefining, relooking, redesigning, and reincorporating HRD in the post COVID-19 context and thereafter. Hum. Resour. Dev. Int. 2020, 23, 438-451. [CrossRef]

72. Kramar, R. Workplace performance: A sustainable approach. Asia Pac. J. Hum. Resour. 2021, 59, 567-581. [CrossRef]

73. Atkinson, J. Manpower strategies for flexible organisations. Pers. Manag. 1984, 16, $28-31$.

74. Lepak, D.; Snell, S. The human resource architecture: Toward a theory of human capital allocation and development. Acad. Manag. Rev. 1999, 24, 31-48. [CrossRef]

75. Bierema, L.L. HRD research and practice after 'The Great COVID-19 Pause': The time is now for bold, critical, research. Hum. Resour. Dev. Int. 2020, 23, 347-360. [CrossRef]

76. Autin, K.L.; Blustein, D.L.; Ali, S.R.; Garriott, P.O. Career development impacts of COVID-19: Practice and policy recommendations. J. Career Dev. 2020, 47, 487-494. [CrossRef]

77. Irfan, S.; Qadeer, F. Employers' investments in job crafting for sustainable employability in pandemic situation due to COVID-19: A lens of job demands-resources theory. J. Bus. Econ. 2020, 12, 124-140.

78. Carlisle, S.; Zaki, K.; Ahmed, M.; Dixey, L.; McLoughlin, E. The imperative to address sustainability skills gaps in tourism in Wales. Sustainability 2021, 13, 1161. [CrossRef]

79. Akkermans, J.; Richardson, J.; Kraimer, M. The COVID-19 crisis as a career shock: Implications for careers and vocational behavior. J. Vocat. Behav. 2020, 119, 103434. [CrossRef] [PubMed]

80. Bowen, J. Lesson learned from the pandemic: The need for sustainable employment. Worldw. Hosp. Tour. Themes 2020, 12, 725-730. [CrossRef]

81. Elkington, J. Enter the triple bottom line. In The Triple Bottom Line: Does It All Add Up? Assessing the Sustainability of Business and CSR; Henriques, A., Richardson, J., Eds.; Earthscan Publications: London, UK, 2004; pp. 1-16.

82. Simpson, B.J.; Radford, S.K. Situational variables and sustainability in multi-attribute decision-making. Eur. J. Mark. 2014, 48, 1046-1069. [CrossRef]

83. He, H.; Harris, L. The impact of COVID-19 pandemic on corporate social responsibility and marketing philosophy. J. Bus. Res. 2020, 116, 176-182. [CrossRef]

84. Aguinis, H.; Villamor, I.; Gabriel, K.P. Understanding employee responses to COVID-19: A behavioral corporate social responsibility perspective. Manag. Res. 2020, 18, 421-438. [CrossRef]

85. Filimonau, V.; Derqui, B.; Matute, J. The COVID-19 pandemic and organisational commitment of senior hotel managers. Int. J. Hosp. Manag. 2020, 91, 102659. [CrossRef]

86. AlZgool, M.; Ahmed, U.; Shah, S.; Alkadash, T.; AlMaamary, Q. Going green during COVID-19: Examining the links between green HRM, green supply chain and firm performance in food Industry of Bahrain: The moderating role of lockdown due to COVID-19. Uncertain Supply Chain. Manag. 2021, 9, 79-88. [CrossRef]

87. Barreiro-Gen, M.; Lozano, R.; Zafar, A. Changes in sustainability priorities in organisations due to the COVID-19 outbreak: Averting environmental rebound effects on society. Sustainability 2020, 12, 5031. [CrossRef]

88. Centre for Research on Energy and Clean Air (CREA). China's Air Pollution Overshoots Pre-Crisis Levels for the First Time. Available online: https://energyandcleanair.org/wp/wp-content/uploads/2020/05/China-airpollution-rebound-final.pdf (accessed on 2 May 2021).

89. Ehnert, I.; Harry, W.; Zink, K.J. Sustainability and HRM. In Sustainability and Human Resource Management; Ehnert, I., Harry, W., Zink, K.J., Eds.; Springer: Berlin/Heidelberg, Germany, 2014; pp. 3-32.

90. Klonek, F.; Parker, S.K. Designing SMART teamwork: How work design can boost performance in virtual teams. Organ. Dyn. 2021, 50, 100841. [CrossRef]

91. Becker, B.E.; Huselid, M.A.; Pickus, P.S.; Spratt, M.F. HR as a source of shareholder value: Research and recommendations. Hum. Resour. Manag. 1997, 36, 39-47. [CrossRef]

92. Shen, H.; Fu, M.; Pan, H.; Yu, Z.; Chen, Y. The impact of the COVID-19 pandemic on firm performance. Emerg. Mark. Financ. Trade 2020, 56, 2213-2230. [CrossRef]

93. Allyn, B. Your Boss Is Watching You: Work-from-home Boom Leads to More Surveillance. Available online: https://www. npr.org/2020/05/13/854014403/your-boss-is-watching-you-work-from-home-boom-leads-to-more-surveillance (accessed on 13 May 2021).

94. Beer, M. HRM at a crossroads: Comments on "Evolution of strategic HRM through two founding books: A 30th anniversary perspective on development of the field". Hum. Resour. Manag. 2015, 54, 417-421. [CrossRef]

95. Beer, M.; Boselie, P.; Brewster, C. Back to the future: Implications for the field of HRM of the multistakeholder perspective proposed 30 years ago. Hum. Resour. Manag. 2015, 54, 427-438. [CrossRef]

96. Boudreau, J.W.; Ramstad, P.M. Talentship, talent segmentation, and sustainability: A new HR decision science paradigm for a new strategy definition. Hum. Resour. Manag. 2005, 44, 129-136. [CrossRef]

97. Taylor, S.; Osland, J.; Egri, C.P. Guest editors' introduction: Introduction to HRM's role in sustainability: Systems, strategies, and practices. Hum. Resour. Manag. 2012, 51, 789-798. [CrossRef]

98. Mason, J. Mixing methods in a qualitatively driven way. Qual. Res. 2006, 6, 9-25. [CrossRef]

99. Rosenzweig, P.M.; Nohria, N. Influences on human resource management practices in multinational corporations. J. Int. Bus. Stud. 1994, 25, 229-251. [CrossRef] 
100. Cooke, F.L. Concepts, contexts, and mindsets: Putting human resource management research in perspectives. Hum. Resour. Manag. J. 2018, 28, 1-13. [CrossRef]

101. Gooderham, P.N.; Nordhaug, O. One European model of HRM? Cranet empirical contributions. Hum. Resour. Manag. Rev. 2011, 21, 27-36. [CrossRef]

102. Mayrhofer, W.; Brewster, C.; Morley, M.J.; Ledolter, J. Hearing a different drummer? Convergence of human resource management in Europe-A longitudinal analysis. Hum. Resour. Manag. Rev. 2011, 21, 50-67. [CrossRef] 